\title{
ENVIRONMENTAL MARKETING: ACCEPTANCE OF PRICE PREMIUM IN THE BRAZILIAN APPAREL INDUSTRY
}

\author{
Áureo Leal \\ Ph.D. Student in Accounting \\ Fucape Business School - FUCAPE. \\ Vitória, Espírito Santo - Brasil. \\ aureo@greensconsult.com \\ Emerson Wagner Mainardes \\ Ph.D. in Management \\ Fucape Business School - FUCAPE. \\ Vitória, Espírito Santo - Brasil. \\ emerson@fucape.br \\ Lucilaine Maria Pascuci \\ Ph.D. in Administration \\ Universidade Federal do Espírito Santo - UFES. \\ Vitória, Espírito Santo - Brasil. \\ lucilaine.pascuci@gmail.com
}

Goal: This study seeks to identify the variables that can influence consumers to pay a premium for the purchase of green products in the apparel industry. It is assumed that the sustainable practices adopted by organizations necessarily imply a price premium to be accepted by the consumer due to associated costs.

Method: Based on variables that consider the binomial marketing and environment, a quantitative and descriptive research was developed. A conceptual framework was tested from a questionnaire applied to 269 respondents. The data were analyzed using the Ordinary Least Square linear regression.

Originality/Relevance: The article discusses relevant issues, as excessive consumption and consumer responsibility, and innovates by introducing the variable 'third party assessments' which has not been commonly used.

Results: The results suggest that third party assessments, and the involvement of the consumer as part of the solution for the environmental issue are the main elements that can positively influence consumers to accept to pay a premium price.

Theoretical/Methodological contributions: The importance of third-party assessment has not been adopted to explain consumer behavior in relation to sustainable products. This study not only innovates by bringing this variable to the model, but also identifies the importance of this practice.

Social/practical contributions to management: For marketers, this research highlights the importance of legitimacy and consumer involvement in solving environmental challenges.

Keywords: Environmental marketing. Price premium. Consumer behavior. Apparel industry.

\section{How to cite the article}

American Psychological Association (APA)

Leal, Á., Mainardes, E. W., \& Pascuci, L. M. (2021, July/Sept.). Environmental marketing: acceptance of price premium in the Brazilian apparel industry. Brazilian Journal of Marketing, 20(3), 437-460. https://doi.org/10.5585/remark.v20i3.19495. 


\section{Introduction}

Historically, the binomial marketing and environment has evolved towards a concept of satisfying not only the needs of the current generation, but perpetuating sustainable solutions in the long run (Peattie, 2001; Ranjan, 2019; White, Habid, \& Hardisty, 2019). This understanding seems to be consistent with the current demands for environmental quality.

However, costs associated to environmental impacts, which are an integral part of the price of sustainable products, are usually not considered for conventional products (Hong, Wang, \& Yu, 2018; Gonzalez-Arcos, Joubert, \& Scaraboto, 2021). Consequently, there is a perception that sustainable products are expensive or unrealistically priced (Solihin, Yulisetiarini, Wihelmina, \& Wardana, 2019). In fact, the competition is unfair, once the conventional products are being subsidized and therefore unrealistically less expensive (Peattie, 2001; Peattie, 2010). In addition, at least in the short term, economy of scale is not present in green production, which feeds costs and prices back even more unfavorably. Therefore, it is natural the existence of a premium embedded in the prices of sustainable products (Joung, Park, \& Ko, 2014).

Eventually, consumers may believe that they play a significant role in the future of environmental quality (Sharaf \& Perumal, 2018). In order to materialize this expectation, they must accept to pay a premium price for environmentally friendly products. The premium supports the internalization of additional costs usually absorbed by the entire society, to produce conventional products (Hong, Wang, \& Yu, 2018).

In this context, this study is seeking to identify the variables that can influence consumers to pay a premium for the purchase of green products in the apparel industry. For this purpose, after a review of the market context, the variables used are presented in order to explain the propensity of the consumers to pay the pricing premium. Further, a conceptual framework is proposed, which is tested based on a questionnaire applied to 269 respondents. The proposed model includes marketing of social causes and ethical attributes, skepticism consumers, proximity of the impacts of the supply chain to the consumer, the convenience factor and selfassessment of consumers' responsibility, as well as social and normative aspects. The results are discussed and the conclusion points out the significant marketing elements that can influence consumers to accept the price premium.

The interest in this industry is justified by its importance in discussions on social and environmental sustainability (Edinger-Schons, Sipila, Sen, Mende, \& Wieseke, 2018; Maksudunov, \& Avci, 2020). The existence of production workshops, where workers are hired 
with wages below the market, with long hours and poor work conditions, often using illegal workers, even in the United States, has made the industry a topic of public interest, by the clear need to curb such practices (Dickson, 1999). In Brazil, the Spanish stores Zara, which operates globally and seen as a phenomenon in the fashion market, admitted the occurrence of slavealike labor in the supply chain of its products in 2011, at the end of a monitoring procedure of the Brazilian Ministry of Labor and Employment (Rolli, 2014).

The review of the literature confirms the existence of studies related to the concept of green marketing, market segmentation and characterization of the green consumer, as well as price sensitivity to environmental marketing claims (Dickson, Waters, \& López-Gydosh, 2012; Kang, Liu, \& Kim, 2013; Joung, Park, \& Ko, 2014; White, Habid, \& Hardisty, 2019; Amoako, Dzogbenuku, \& Abubakari, 2020). However, no research has been identified on the relationship between consumers of apparel products and sales efforts, considering the Brazilian market (Martinez, 2010; Brandão, Alexander Anez, \& Costa, 2011; Ribeiro \& Veiga, 2011; Choi \& Ng, 2011; Pereira Heath \& Chatzidakis, 2012; Stall-Meadows \& Davey, 2013; Lopes \& Pacagnan, 2014; Sharaf, M. A., \& Perumal, 2018).

The literature review also suggests that researchers have already pointed out consumer skepticism when it comes to green products. But, again, no studies have been found that have empirically tested the role of third part valuation in price sensitivity by apparel consumers (Macnaghten, Grove-White, Jacobs, \& Wynne, 1995; Roberts, 1996; Connelly, Ketchen Jr, \& Slater, 2011; Solihin, Yulisetiarini, Wihelmina, \& Wardana, 2019).

Given the context presented, this research presents some relevant contributions. The first one is to discuss price sensitivity to environmental marketing claims within the domain of textile and apparel products in an emerging economy, characterized by rapid urbanization and economic growth. Under these circumstances, it has been identified a lack of public awareness about its relationship with environmental degradation (Chan \& Lau, 2000). As a second contribution, the study models the consumers' propensity to pay the premium price with an additional explanatory variable: third-part assessment. This additional variable widens the discussion and supports the international trend of integration of financial annual reports and sustainability reports, as proposed by the Sustainability Accounting Standards Board (SASB), International Integrated Reporting Council (IIRC) and Global Reporting Initiative (GRI). 


\section{Theoretical Foundation}

\subsection{Economic context}

Currently, most organizations develop some sustainability program, but the challenge seems to be moving from isolated initiatives to a corporate strategy (Eccles, Ioannou, \& Serafeim, 2011; Eccles \& Serafeim, 2013). This development is slow and requires a combination of legislation, taxes, consumer action, innovation, and corporate leadership (Peattie, 2010; Gonzalez-Arcos, Joubert, \& Scaraboto, 2021).

An organization that positively evaluate the added value of social-environmental initiatives can do so in different ways. Among the possibilities it can focus on assessing longterm financial performance (Brochet, Loumioti, \& Serafeim, 2013), paying more attention to the impacts of this operations on the environment and communities (Paine, 2004), establish higher ethical standards (Paine, 2004), implement sophisticated stakeholders management systems (Freeman, Harrison, \& Wicks, 2007), among others initiatives. Traditionally, additional costs arising from such decisions would be absorbed by the society and the internalization of these costs must necessarily be offset by aggregate economic value (Eccles, Ioannou, \& Serafeim, 2011).

With regard to the textile and clothing chain in the world, in particular, it is of outstanding importance, both for its for its potential impact on the environment. The environmental impact of textile production is significant and extends throughout the product's life cycle: raw materials, production, cleaning and disposal (Chen \& Burns, 2006). Challenges include the ability to renew raw materials, the toxicity of the chemicals and pesticides used in manufacturing and cleaning processes, the very high-water consumption, as well as aspects related to recycling and biodegradability (Kang, Liu, \& Kim, 2013).

According to the report of the International Programme on the Elimination of Child Labour (2013), although estimates suggest child labor decreased by 30\% between 2000 and 2012, children who work below the required minimum age or detriment are still represent $11 \%$ of the world's children. Many of these child laborers work within the fashion supply chain, making the textiles and garments to satisfy the demand of consumers in Europe, the United States, and beyond (Moulds, 2015). The 'environmentally responsible' label can rarely be applied properly to textile products (Chen \& Burns, 2006).

Brazil, in turn, can be considered an important market due to its significant presence in the global economy, with a diversified industrial capacity, and its large population, with important European and African influences (Baer, 2001). Despite the inclusion of 40 million 
people in the ranks of Brazilian's middle class between 2003 and 2011, Brazil still faces major social challenges, especially in terms of inequality in the distribution of wealth. Consequently, there has been and increasing use of natural resources and environmental depletion (Barcellos et al., 2014).

\subsection{Social causes marketing}

There are different practices that can be adopted by organizations interested in acting or strengthening their performance - in a social-environmental way. A widely adopted practice is the introduction of its environmental commitment as a corporate and institutional philosophy, as opposed to a tactical and administrative approach (Varadarajan, 1992; Menon \& Menon, 1997; Han, \& Stoel, 2017). An illustration of this practice is a corporate commitment to contribute with a value - donation - to a given cause, conditioned to a favorable decision by the consumer when purchasing its products. Thus, the donation can meet the organizational and individual objectives, simultaneously (Varadarajan \& Menon, 1988).

In this way, the donation could serve both organizational and individual goals, simultaneously (Varadarajan \& Menon, 1988). As a result, a positive relationship between corporate giving and favorable consumer behavior in relation to the company's products (Koschate-Fischer, Stefan, \& Hoyer, 2012).

A similar way of expressing this corporate and institutional commitment is to promote campaigns based on ethical attributes. In this context, if the marketing effort is be able to awaken consumers to their own responsibility, they can assess their fear of future guilt, which can determine the decision to purchase a product that assuages this feeling (Peloza, White, \& Shang, 2013).

\subsection{Skeptical consumers}

The response of consumers to marketing appeals, in general, is a function of the belief that they have the power to positively influence actual results in the real world (Straughan \& Roberts, 1999; Han, \& Stoel, 2017; Edinger-Schons, Sipila, Sen, Mende, \& Wieseke, 2018). The ability to influence the improvement of the environmental conditions perceived by the consumer is highly correlated with the environmentally conscious consumer behavior and is in itself the strongest builder of his behavior. Therefore, consumers accept to pay the additional amount only if green products have characteristics that they can accredit (Roberts, 1996; Joung et al., 2014; Taufique, Vocino, \& Polonsky, 2017). 
This same understanding is assumed by Singh and Vij (2011) who identified consumers who believe that advertising can mislead and manipulates individuals to buy in excess and even buy unnecessary things. Also, the research carried out by Stall-Meadows and Davey (2013) on apparel industry highlighted the value of the credibility of marketing claims, as well. They must be accurate and qualified to gain legitimacy.

In this context, government and organizations are commonly seen as part of the system with a tendency to self-interest and short-term goals (Macnaghten, Grove-White, Jacobs, \& Wynne, 1995). Consequently, even if people are not familiar with the idea of sustainability, when presented to this issue, they recognize them positively in terms of its values and priorities. On the other hand, they are very skeptically about the ability of government and organizations to genuinely promote sustainability (Macnaghten, Grove-White, Jacobs, \& Wynne, 1995).

In order to minimize skepticism, the option of promoting a progressive integration of environmental and social practices into business models already represents a new and relevant initiative. This is an important change that can reduce information asymmetry, in addition to making it easier for consumers assess the authenticity of organizations (Connelly, Ketchen Jr., \& Slater, 2011).

\subsection{Proximity to the consumer}

In typical cause-related marketing campaigns of, an important element is the personal or emotional involvement of consumers with the cause in question (Han, \& Stoel, 2017). A research by Brodericki, Jogi and Garry (2003), on a breast cancer awareness campaign, showed the importance of the issue for some consumers, since breast cancer can directly affect them or, also, due to the fact that they knew someone close who has already been affected. This research also identified a sense of solidarity and defense, possibly due to a more intimate connection with the topic in question, positively influencing the campaign's results.

According to Diamantopoulos, Schlegelmilch, Sinkovics and Bohlen (2003), consumer behavior in relation to environmental issues is a function of situational factors, such as direct exposure to any negative impact that may exist due to the organization's activity. The research mentioned is in line with the consumer psychological distance theory (Spence, Poortinga, \& Pidgeon, 2012), according to which consumers tend to be more sensitive to issues closer to their reality. However, different consumers can manifest themselves in diverse ways. 


\subsection{Convenience}

An important aspect regarding consumer behavior is to recognize the difference between convenience and consistency in their consumption practices. McDonald and Oates (2006) tested empirically and confirmed Peattie's (1999) theoretical prediction for the process of purchasing a green product. The theoretical prediction suggests the absence of a green consumer, but in fact the existence of a green purchasing. In this view, the consumers act differently depending on the circumstances. In other words, he acts in a convenient and not consistent way, when considering the effort, he needs to make to accept certain characteristics of what he intends to buy, including the price and the effective result that this decision will produce in environmental terms. In short, the consumer ponders its level of commitment and the level of confidence he has that the purchase will produce useful results.

The variable convenience is related to the perceived effectiveness by the consumer. It is the perception of consumers of how much their consumption will positively favor, or less harm, the environment (Roberts, 1996; Akehurst et al., 2012; Straughan \& Roberts, 1999; Chen \& Chang, 2013; Antonetti \& Maklan, 2014; Gershoff \& Frels, 2015; White, Habib, \& Hardisty, 2019).

Excessive consumption can be another important aspect in terms of analyzing the behavior of consumer of green products according to research by Pereira, Heath and Chatzidakis (2012). Consumers, in general, perceive the level of excessive consumption in the society they live, but they attribute full responsibility to the organizations' marketing system. A denial of responsibility occurs when attributing it to third parties, including the educational system or society in general, therefore, blaming the marketing system acts as a way of moving personal responsibility (Pereira Heath \& Chatzidakis, 2012; Solihin, Yulisetiarini, Wihelmina, \& Wardana, 2019).

\subsection{Social and normative aspects}

Social media has significantly changed the way consumers and producers interact. It made possible, for example, to exchange of information among a multitude of geographically dispersed consumers. This intense exchange of information can reach and influence people, allowing customers to integrate resources when interact with other and, thus, co-create and use them during consumption (Zadeh et al., 2019).

Although there are some controversies among researchers regarding the relationship between normative, social aspects, and favorable attitudes towards the environment, Pristl et al. 
(2021) recognizes that sustainable consumption has stood out, among other reasons, due to social pressure. Even so, the same authors highlight that pro-environmental behavior and sustainable consumption can be effectively encouraged by normative and social aspects.

Regarding the apparel industry, according to Kang, Liu and Kim (2013), social norms can put significant pressure on people to buy sustainable clothes. In this respect, both social networks and social media can play an important normative and social role.

\subsection{Proposed model}

The references above suggest that the belief that environmental quality can be improved by consumer behavior is directly associated with consumers' internal and external motivators. External Motivators (EM), in turn, include marketing messages, whose goal is to improve awareness of environment weaknesses, as well as advertising of green products and institutional commitment, cause-related marketing, educational campaigns sponsored by government, and the availability of recycling centers and collection points (Mainardes et al, 2017).

For the purpose of this research and based on the aforementioned studies, four variables are proposed to capture the source of information available to consumers, two variables to assess their proximity to problems caused by environmental degradation and four different marketing strategies (Figure 1).

Internal motivators encompass all constructs that are under the control of the consumer and reflect individual attitudes and concerns. Two variables have been proposed to capture personal and individual motivators: green attitude and environmental concern (Figure 1). Finally, as a dependent variable, green behavior is captured by variable Y1, i.e., consumer's concern with the impacts of consumption behavior on nature and communities. 
Figure 1 - Proposed model

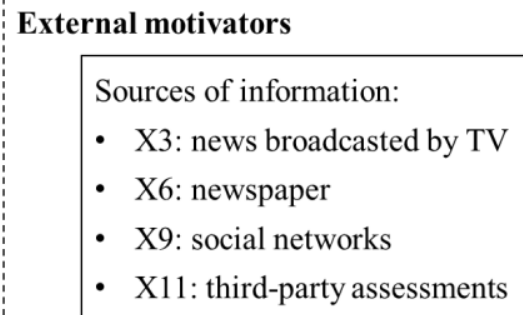

Proximity to problems caused by environmental degradation:

- $\mathrm{X} 4=$ direct connection to the affected people

- X5 = direct connection with aspects of nature affected

Marketing appeals:

- X7: philanthropy or donation

- X8: consumer's responsibility call

- X10: articles from specialized magazines

- X12: institutional commitment

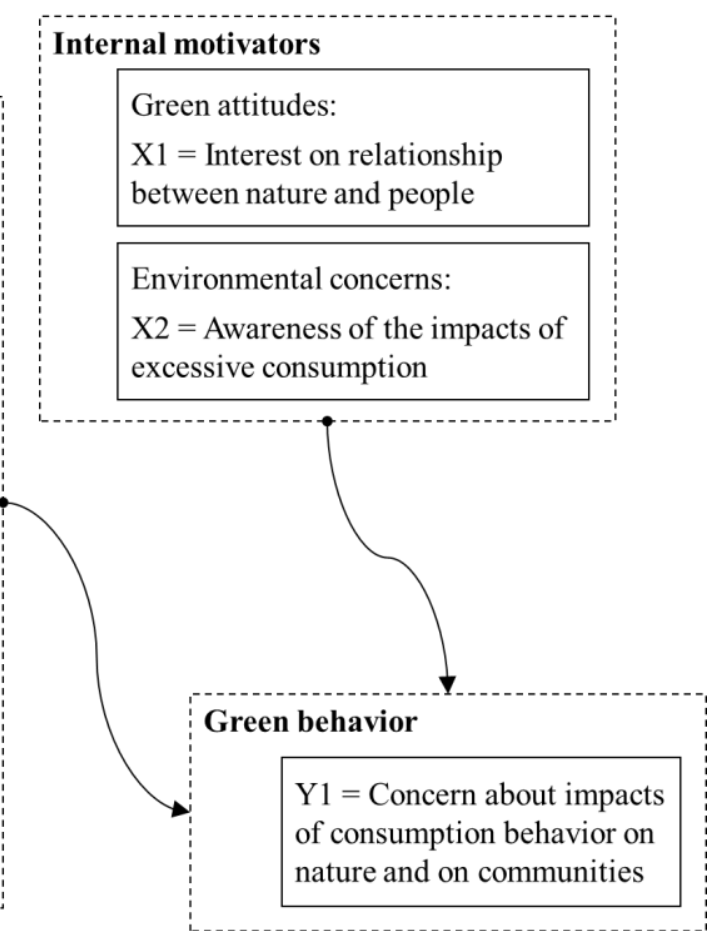

Source: Authors.

\section{Method}

In order to identify the variables that can influence consumers to pay a premium for the purchase of green products in the apparel industry, a quantitative and descriptive research was adopted. The proposed model was developed in line with the literature, since the variables adopted were extracted from different studies (see Appendix 1).

The population was represented by consumers of apparel in general, clothes and accessories, assuming that respondents routinely buy clothes. The sample can be characterized as non-probabilistic, as it did not seek respondents from a specific segment, related to the cause of the environment, or even working in a sector with special interest in the subject. Based on these characteristics, the sample is appropriate for the purpose of this study, with no evidence of bias, however there is no evidence they are representative of the population.

People were randomly selected, as they accepted the invitations posted on social media. It was sent 1,500 questionnaires to people who expressed a willingness to participate in the survey. Of these, it was obtained 269 complete responses, representing a rate of return of $18 \%$.

The questionnaire was designed from several studies related to the binomial marketing and environment (Varadarajan \& Menon, 1988; Macnaghten et al., 1995; Menon \& Menon, 1997; Straughan \& Roberts, 1999; Broderick, Jogi, \& Garry, 2003; Connelly, Ketchen Jr., \& 
Slater, 2011; Pereira Heath \& Chatzidakis, 2012; Kang, et al., 2013; Peloza, White, \& Shang, 2013). A questionnaire with 17 questions was adopted, with 13 questions representing each variable to be analyzed, using the seven-position Likert scale (from totally disagree to totally agree). The questionnaire also included four questions of demographic characterization, multiple choice, which were used as controls. The control variables are as follows: age, gender, formal education level and income level of the consumer.

The questionnaire was validated in two stages: the content was validated by two experts on the subject. In the sequence, it was performed the face validation, with a pre-test with 12 people belonging to the target audience of the study. The questionnaire was applied from September $15^{\text {th }}$ to October $17^{\text {th }}, 2016$, using Google Forms for data collection. The data were analyzed using SPSS 22. The statistical model adopted was linear regression by Ordinary Least Square (OLS).

Considering that a direct question about the respondent's intention to pay the premium price could bias the result, the respondent's self-assessment of their behavior and attitude towards socio-environmental impacts was chosen as a proxy. In other words, it was assumed that consumers who define themselves as environmentally responsible are possible more likely to accept paying the premium price for sustainability.

\section{Data analysis}

The sample, with 269 valid responses (Marshall, 1996), can be demographically characterized as predominantly male (58.7\%), with a college degree (98.5\%), over 30 years old $(82.5 \%)$ and relatively income high $(71.7 \%)$, as shown in Table 1.

Table 1 - Demographics of Sample

\begin{tabular}{|l|c|c|}
\hline \multicolumn{1}{|c|}{ Gender } & Frequency & $\%$ \\
\hline Female & 111 & 41.3 \\
\hline Male & 158 & 58.7 \\
\hline Total & 269 & 100.0 \\
\hline
\end{tabular}

\begin{tabular}{|l|c|c|}
\hline \multicolumn{1}{|c|}{ Education } & Frequency & $\%$ \\
\hline High school & 4 & 1.5 \\
\hline College & 265 & 98.5 \\
\hline Total & 269 & 100.0 \\
\hline
\end{tabular}

\begin{tabular}{|c|c|c|}
\hline Age & Frequency & $\%$ \\
\hline Below 30's & 47 & 17.5 \\
\hline Between 30 and 40 & 77 & 28.6 \\
\hline Above 40 's & 145 & 53.9 \\
\hline Total & 269 & 100.0 \\
\hline
\end{tabular}

\begin{tabular}{|l|c|c|}
\hline Monthly Salary & Frequency & $\%$ \\
\hdashline Below R $\$ 1.000$ & 3 & 1.1 \\
\hline $\mathrm{R} \$ 1.000-\mathrm{R} \$ 5.000$ & 73 & 27.1 \\
\hline Above $\mathrm{R} \$ 5.000$ & 193 & 71.7 \\
\hline Total & 269 & 100.0 \\
\hline
\end{tabular}

Source: Elaborated by the authors. 


\subsection{Descriptive Statistics}

All 269 responses scored, at least once, the minimum value of 1 and the maximum of 7. As shown in Table 2, the descriptive statistics presented averages in the interval from 4.1 to 5.2 (the center of the scale is 4), standard deviation ranging from 1.4 to 1.8 , and coefficient of variation from $29 \%$ to $43 \%$. The variables from X1 up to X12 are independent variables and Y1 is the dependent variable.

Table 2 - Description of variables and results

\begin{tabular}{|c|c|c|c|c|c|}
\hline \multicolumn{2}{|r|}{ Dependent and Independent Variables } & \multirow{2}{*}{$\begin{array}{l}\qquad \text { Reference } \\
\text { (Macnaghten et al., 1995; Straughan \& } \\
\text { Roberts, 1999) }\end{array}$} & \multirow{2}{*}{$\begin{array}{l}\text { Avg } \\
(\mathbf{M})\end{array}$} & \multirow{2}{*}{$\begin{array}{c}\text { Std } \\
\text { Dev } \\
\text { (SD) }\end{array}$} & \multirow{2}{*}{$\begin{array}{r}\text { M/SD } \\
(\mathbf{C o V}) \\
41 \%\end{array}$} \\
\hline $\mathrm{X} 1$ & $\begin{array}{l}\text { Interest for the relationship between nature, people in } \\
\text { the community and apparel industry }\end{array}$ & & & & \\
\hline $\mathrm{X} 2$ & $\begin{array}{l}\text { Awareness of the impacts of excessive consumption } \\
\text { to the nature }\end{array}$ & $\begin{array}{l}\text { (Pereira Heath \& Chatzidakis, 2012; } \\
\text { Straughan \& Roberts,1999) }\end{array}$ & 4.1 & 1.8 & $43 \%$ \\
\hline $\mathrm{X} 3$ & $\begin{array}{l}\text { Influence of television reports, showing actual results, } \\
\text { on the price sensitivity }\end{array}$ & (Connelly, et al., 2011) & 4.7 & 1.5 & $32 \%$ \\
\hline $\mathrm{X} 4$ & $\begin{array}{l}\text { Influence of direct connection to the affected people } \\
\text { on the price sensitivity }\end{array}$ & (Broderick, Jogi, \& Garry, 2003) & 5.1 & 1.5 & $30 \%$ \\
\hline X5 & $\begin{array}{l}\text { Influence of direct connection with aspects of nature } \\
\text { affected on the price sensitivity }\end{array}$ & (Broderick, Jogi, \& Garry, 2003) & 5.0 & 1.5 & $30 \%$ \\
\hline $\mathrm{X} 6$ & $\begin{array}{l}\text { Influence of direct advertising in the media on the } \\
\text { price sensitivity }\end{array}$ & (Connelly, et al., 2011) & 4.6 & 1.4 & $31 \%$ \\
\hline $\mathrm{X} 7$ & $\begin{array}{l}\text { Influence of philanthropy or donation on the price } \\
\text { sensitivity }\end{array}$ & (Varadarajan \& Menon, 1988) & 4.7 & 1.5 & $32 \%$ \\
\hline $\mathrm{X} 8$ & $\begin{array}{l}\text { Influence of sharing the responsibility with the } \\
\text { consumer on the price sensitivity }\end{array}$ & (Peloza, White, \& Shang, 2013) & 4.3 & 1.5 & $35 \%$ \\
\hline X9 & $\begin{array}{l}\text { Influence of appeals through social networks on the } \\
\text { price sensitivity }\end{array}$ & (Kang, Liu, \& Kim, 2013) & 4.3 & 1.6 & $37 \%$ \\
\hline $\mathrm{X} 10$ & $\begin{array}{l}\text { Influence of appeals through articles in specialized } \\
\text { magazines on the price sensitivity }\end{array}$ & $\begin{array}{l}\text { (Macnaghten et al., 1995; Connelly, et al., } \\
\text { 2011) }\end{array}$ & 4.8 & 1.4 & $30 \%$ \\
\hline $\mathrm{X} 11$ & $\begin{array}{l}\text { Influence of third-party assessments on the price } \\
\text { sensitivity }\end{array}$ & $\begin{array}{l}\text { (Macnaghten et al., 1995; Connelly, et al., } \\
\text { 2011) }\end{array}$ & 5.2 & 1.5 & $29 \%$ \\
\hline $\mathrm{X} 12$ & $\begin{array}{l}\text { Influence of institutional commitment on the price } \\
\text { sensitivity }\end{array}$ & $\begin{array}{l}\text { (Connelly, et al., 2011; Menon \& Menon, } \\
\text { 1997) }\end{array}$ & 5.0 & 1.5 & $31 \%$ \\
\hline Y1 & $\begin{array}{l}\text { Concern about impacts of consumption behavior on } \\
\text { nature and on communities }\end{array}$ & $\begin{array}{l}\text { (Pereira Heath \& Chatzidakis, 2012; } \\
\text { Straughan \& Roberts,1999) }\end{array}$ & 4.7 & 1.6 & $34 \%$ \\
\hline
\end{tabular}

Source: Elaborated by the authors.

\subsection{Inference}

Using a variable to represent environmentally responsible behavior, the regression model with the dependent variable Y1 (Consumer concerned with the impacts of consumption behavior on nature and people in the communities) presented an Adjusted $\mathrm{R}^{2}$ of 0.303 . For Adjusted $\mathrm{R}^{2}$, a value of 0.20 or above indicates an acceptable linearity of a relationship (Azasu, 2009). It is important to emphasize that, for the purpose of this study, the Adjusted R2 was used 
only to verify the linearity of the model. In addition, in psychometric surveys, Adjusted $\mathrm{R}^{2}$ results above $25 \%$ are considered good due to the complexity of human behavior (Chen \& Chang, 2013).

From this result, question Y1 was used as a proxy to infer the willingness of consumers to pay a premium price for sustainable products and became the focus of further analysis. The model designed to identify the explanatory variables that are statistically significant to explain the consumer propensity to pay the price premium for sustainable products is a multiple linear regression, solved by OLS, with 5\% significance level. The model is represented by Equation 1.

$$
Y 1=\alpha+\beta 1 X 1+\beta 2 X 2+\cdots+\beta 12 X 12+\text { controls }+\varepsilon \quad \text { (Equation } 1)
$$

The explanatory variables were previously defined (see Table 2). The results of the regression, with Adjusted $\mathrm{R}^{2}$ equals to $30.3 \%$, are shown in Table 3 and Table 4 . Also, the validity of the sample was verified. Outliers, multicollinearity, randomness, normality of residue distribution, homoscedasticity and variance tests were performed. As no problems were detected, the sample was considered valid. The presence of latent variables was also verified, with no latent variables found that grouped the tested variables. In addition, the results of the correlations among the variables and the ANOVA test of the model are presented in Appendix 2.

The explanatory variables for which the null hypothesis is rejected $\left(H_{0}=0\right)$ are: 'sharing responsibility with the consumer' (X8) and 'third party assessments' (X11), both with p-value smaller than 0.05 . Therefore, the ability of the marketing discourse to share with consumers responsibility to solve environmental challenges and the accreditation provided by third party assessments are the only two explanatory variables that by explain the propensity of consumers to pay a price premium for green apparel products, considering this sample.

The control variables included in the model are as follows: age, gender, formal education level and consumer income level. Of these control variables, only age was found to be significant. 
Table 3 - Model summary ${ }^{\mathrm{d}}$

\begin{tabular}{|c|c|c|c|c|c|c|c|c|c|c|}
\hline \multirow{2}{*}{ Model } & $\mathbf{R}$ & $\begin{array}{c}\mathbf{R} \\
\text { Square }\end{array}$ & $\begin{array}{c}\text { Adj } \mathbf{R} \\
\text { Square }\end{array}$ & Std Error & $\begin{array}{c}\text { R Square } \\
\text { Change }\end{array}$ & F Change & df1 & df2 & $\begin{array}{c}\text { Sig. F } \\
\text { Change }\end{array}$ & $\begin{array}{c}\text { Durbin- } \\
\text { Watson }\end{array}$ \\
\hline 3 & $.557^{\mathrm{c}}$ & .310 & .303 & 1.31996 & .016 & 6.318 & 1 & 265 & .013 & 1.928 \\
\hline
\end{tabular}

Source: Research data. a. Predictors: (Constant), X11, X8, AGE. b. Dependent Variable: Y1.

Table 4 - Coefficients ${ }^{\mathrm{a}}$

\begin{tabular}{|c|c|c|c|c|c|c|c|c|c|c|c|c|c|}
\hline & \multirow{2}{*}{ Model } & \multicolumn{2}{|c|}{$\begin{array}{c}\text { Nonstandard } \\
\text { coefficients }\end{array}$} & \multirow{2}{*}{$\begin{array}{c}\begin{array}{c}\text { Standardized } \\
\text { coefficients }\end{array} \\
\text { Beta }\end{array}$} & \multirow[t]{2}{*}{$\mathbf{T}$} & \multirow{2}{*}{ Sig. } & \multicolumn{2}{|c|}{$\begin{array}{c}95,0 \% \\
\text { Confidence } \\
\text { Interval for B } \\
\end{array}$} & \multicolumn{3}{|c|}{ Correlations } & \multicolumn{2}{|c|}{$\begin{array}{c}\text { Collinearity } \\
\text { statistics }\end{array}$} \\
\hline & & $\mathbf{B}$ & $\begin{array}{c}\text { Standard } \\
\text { Error }\end{array}$ & & & & $\begin{array}{l}\text { Lower } \\
\text { bound }\end{array}$ & $\begin{array}{l}\text { Upper } \\
\text { bound }\end{array}$ & $\begin{array}{l}\text { Zero- } \\
\text { order }\end{array}$ & Partial & Part & Tolerance & VIF \\
\hline \multirow{4}{*}{3} & (Const) & 1.070 & .370 & & 2.893 & .004 & .342 & 1.799 & & & & & \\
\hline & X11 & .386 & .066 & .374 & 5.809 & .000 & .255 & .517 & .516 & .336 & .296 & .629 & 1.590 \\
\hline & $\mathrm{X} 8$ & .222 & .068 & .210 & 3.283 & .001 & .089 & .355 & .445 & .198 & .167 & .635 & 1.576 \\
\hline & AGE & .267 & .106 & .129 & 2.514 & .013 & .058 & .477 & .187 & .153 & .128 & .986 & 1.014 \\
\hline
\end{tabular}

Source: Research data. a. Dependent Variable: Y1

\section{Results and discussion}

Considering that the center of the scale is 4 and the results in Table 2, consumers have interest on the relationship between nature, people in the community, and the apparel industry just above the average (X1, M=4.2), which can be interpreted as some indifference, or absence of interest. This interpretation seems to be in line with the apparent lack of awareness about the impacts that excessive consumption has on nature $(X 2, M=4.1)$, also above average.

Comparing these numbers with the concern of consumers with the impacts of consumption on nature and community ( $\mathrm{Y} 1, \mathrm{M}=4.7)$, which has a higher average, it is possible to perceive a gap between the perception of feeling worried and the positioning proactive to be interested and be aware of such impacts. In addition, comparing the coefficients of variation between these three variables reveals that is better agreement among consumers in terms of concern with consumption behavior in nature and community (Y1, CoV=34\%), but less agreement in terms of interest and awareness of their excessive consumption (X1, CoV=41\% and $\mathrm{X} 2, \mathrm{CoV}=43 \%)$.

Apparently, there may be a gap between the tendency to worry about sustainability and the availability of time to focus on this issue, as well as the attitude to accept responsibility for the situation. This observation corroborates with aligned with the research by Pereira Heath and Chatzidakis (2012), which highlights a denial of responsibility when consumers consider the marketing system and third parties - including the educational system or society in general - the responsible for solving the environmental challenges. In addition, there may be a gap between environmental attitudes and behaviors, indicating that consumers who claim to be pro- 
environment may fail to act in this way for internal and external reasons (Zhao et al., 2014). This gap become especially important when consumers realize fewer benefits than green products claim (Pinto et al., 2011; Tseng and Hung, 2013) or when high prices and low quality become barriers to increase green purchase habits (Ritter et al., 2014).

Among the variables intended to test the elements of the marketing discourse, the influence of institutional commitment (X12; M=5.0) suggests that a clear signal of corporate intentions (Connelly, Ketchen Jr., \& Slater, 2011) can leverage positive consumer behavior. The importance of signage increases the influence of third-party assessments on price sensitivity (X11; M=5.2). Both aspects, institutional commitment and third-party assessments, deal with the issue, i.e., government and organizations are commonly seen as part of the system, with a tendency towards self-interest and short-term goals, as already mentioned by Macnaghten et al. (1995) and Ritter et al. (2015).

Finally, among the elements of the marketing discourse, typically conventional marketing approaches such as TV reports (X3, M=4.7), published advertising (X6, M=4.6), philanthropy or donation (X7, M=4.7), social networks (X9, M=4.3), as well as specialized magazines $(\mathrm{X} 10, \mathrm{M}=4.8)$ are still important as marketing tools, but less than the previous ones. Apparently, the sample used in this research, characterized by high level of education and income, is not sensitive to conventional approaches requiring a different strategy from marketers, at least for the context of green products in the apparel industry.

To measure the influence of proximity to impacts, the high averages of direct connection with the affected people (X4; M=5.1) and direct connection to affected aspects of nature (X5; $M=5.0$ ) suggest that marketing environmental should draw the attention of consumers to those aspects close to their experience. As shown by Broderick, Jogi and Garry (2003) and also by White, Habid and Hardisty (2019), the proximity to environmental problems brings awareness and involvement, and the emotional level of individual involvement is a key factor in shaping consumer behavior. Therefore, sustainable product marketing efforts must focus on local issues, as opposed to general and distant causes. In this way, consumers can associate the issue with its own experience, stimulating the expected behavior.

This change is challenging when it comes to the textile supply chain, since environmental impacts are often left behind in agricultural areas or in industrial areas far from consumption - such as Panama, China, and South Asia, among others (International Programme on the Elimination of Child Labour (IPEC), 2013). Consumers are usually unaware; therefore, they are in a position to associate this reality with a marketing discourse, eventually developed 
by a socially responsible organization (Wang, Krishna, \& McFerran, 2016) in the apparel industry.

In order to identify the statistically significant factors that influence the decision to accept a price differential, the results of the estimation model are presented in Table 4. At 95\% confidence, only the third-party assessment variables of the results claimed by the organizations (X11; Beta=0.386) and the ability of organizations to include consumers as part of the solution, awakening in some way the sense of shared responsibility (X8; Beta=0.222) are statistically related to the consumers' decision to accept a price differential for sustainable apparel products in the Brazilian market.

In this context, there is a direct relationship with the consumer skepticism. That is, they require independent mechanisms to corroborate organizational claims. The considerable number of sustainable products on the market may explain, at least in part, the development of such behavior. From this perspective, this finding may represent an opportunity for marketers since being reliable can lead to loyalty and even a favorable attitude to pay for the benefit that is expected by consumers of sustainable apparel products.

The use of third-party assessment variable is an innovation that has proved to be relevant to explain consumer behavior - in the case of sustainable products - and reinforces the importance of the international trend to integrate annual financial and sustainability reports. This integration has been an initiative of regulatory agencies and professional institutions, such as the Sustainability Accounting Standards Board (SASB), International Integrated Reporting Council (IIRC) and Global Reporting Initiative (GRI), for example. This is the case of a Brazilian company in the cosmetics industry, for example, which is among the pioneer organizations to adopt innovative standards of annual financial statements, with integration of social, environmental and financial information (Eccles \& Serafeim, 2013; Maksudunov, \& Avci, 2020).

When the denial of responsibility is overcome by the marketing effort on the part of the organization seeking to bring consumers closer to the environmental problem and share the responsibility for the solution (Han, \& Stoel, 2017; White, Habib, \& David, 2019), the latter feel more inclined to buy their products, despite higher prices. This research reveals, therefore, a consumer who is not very interested in the subject and is somewhat reactive in assuming its share of responsibility.

The results presented are consistent with the research by Stall-Meadows and Davey (2013) and also by Han \& Stoel (2017) which highlighted the value of the credibility of 
marketing claims, which need to be accurate and qualified to gain legitimacy. It is also in line with the results of the research by Peloza, White and Shang (2013) according to which consumers can be favorably influenced to accept a price premium for green products, when marketing efforts succeed in inciting consumers' awareness of their own responsibility in this process. Therefore, the efforts to make consumers in regard their own role is worthy, once an educated consumer may behave positively towards sustainable products.

In this context, a better understanding of how to change consumer behavior to be more sustainable still remains a general concern, as highlighted by White, Habid and Hardisty (2019). In this sense, it is important to remember that different cultures around the world have a different impact on consumer behavior (Sharaf \& Perumal, 2018). And yet, that habits take time to change, so, although it is desired that the respondents' opinions have changed since this research was carried out, unfortunately, the evidence (Gonzalez-Arcos, Joubert, \& Scaraboto, 2021) shows that there is still a long way to go.

\section{Conclusion}

This study aimed to identify the variables that can influence consumers to pay a premium for the purchase of green products, using for this purpose the case of apparel industry and a sample from Brazil. The apparel industry was selected due to its potential impact, both socially and environmentally. The Brazilian market can be considered significant in the global economy, because its diversified industrial capacity and large population.

The results showed a consumer only moderately interested in the topic of sustainability in the apparel industry, as well as moderately aware of the consequences of excessive consumption on environmental quality. However, the consumers who took place in this survey, showed concern about the impact of their consumption behavior both in nature and communities. There seems to be some distance between the tendency to worry about the situation and a more positive attitude.

Although it is not significant to explain the decision to pay a premium price for sustainable products, this research highlighted the importance of consumer's proximity to the impacts caused on nature and the community. This result suggests that approaches that seek to bring the consumer closer to the problems caused by conventional production practices may be more effective for organizations focused on sustainable textile products.

In addition, the study showed a consumer skeptical about the authenticity of the practices adopted by the government and organizations. In view of this finding, this study 
suggests that organizations should submit the results of their green initiatives to third-party evaluation, in order to validate the practices adopted in the pursuit of the desired legitimacy. In this sense, the marketing efforts of socially responsible organizations should involve consumers as part of the solution. That is, it encourages them to accept their responsibility to improve environmental conditions. To this end, the results of this research suggest that efforts should be made on issues close to the consumer's reality. Also, the importance of signaling the institutionalization of the sustainability theme was confirmed, as an integral part of the corporate strategy.

In terms of academic field, in addition to confirming previous research and providing statistical data to deepen the discussion on consumer behavior and attitude towards sustainable products, this research introduced a variable rarely used in the literature: the evaluation of third parties. The importance of third-party assessment has not been commonly adopted to explain consumer behavior in relation to sustainable products. Therefore, this study not only innovates by adopting this variable in the model, but also identifies the importance of this practice. With regard to the practical contribution of the study to marketers, the results highlight the importance of legitimacy and the involvement of consumers in solving environmental challenges.

A limitation of this research concerns the sample being non-probabilistic and transversal, which does not allow generalizing the results. However, the findings bring evidence of behaviors that can be confirmed in future studies, through probabilistic sampling and with research being carried out over time, observing changes in consumer behavior. The fact that this research considers only Brazilian consumers in a single sector (textile sector) is also presented as a limitation. Cultural aspects and characteristics specific to each industry can reflect on the results obtained by this study. Thus, it is recommended to replicate this research in other countries and in other industries in order to observe impacts of cultural differences and between sectors of the economy, which can contribute to making the results more robust.

In addition, future studies can also deepen the discussion using samples from younger people. It can be considered that another generation may have a less skeptical stance, since environmental legislation has evolved and the involvement of young people with social causes has increased. Another suggestion is to consider research services and products in the future with a closer relationship with the environmental quality experienced by consumers. This is the case of transport services and the oil and gas industry, for example, where the proximity of the consumer to the resulting impacts of such products and services could achieve different results. 


\section{Acknowledgements}

This research was supported by Brazilian National Council for Scientific and Technological Development (CNPq/Brazil), project 304209/2018-0 and 425016/2018, by Foundation for Research Support of Espírito Santo (FAPES/Brazil), projects 84513772 (599/2018), 555/2018, 85395650 (228/2019), 141/2019 and 30007011003P2 (02/2018), by Portuguese Science Foundation (FCT/Portugal) through NECE (Núcleo de Estudos em Ciências Empresariais), project UID/GES/04630/2020, and by IFTS (Instituto Fucape de Tecnologias Sociais), project 2018-2021.

\section{References}

Akehurst, G., Afonso, C., \& Martins Gonçalves, H. (2012). Re-examining green purchase behaviour and the green consumer profile: new evidences. Management Decision, 50(5), 972-988. https://doi.org/10.1108/00251741211227726

Amoako, G.K., Dzogbenuku, R. K. \& Abubakari, A. (2020), Do green knowledge and attitude influence the youth's green purchasing? Theory of planned behavior, International Journal of Productivity and Performance Management, 69(8), 1609-1626. https://doi.org/10.1108/IJPPM-12-2019-0595

Antonetti, P., \& Maklan, S. (2014). Feelings that make a difference: how guilt and pride convince consumers of the effectiveness of sustainable consumption choices. Journal of Business Ethics, 124(1), 117-134. https://doi.org/10.1007/s10551-013-1841-9

Baer, W. (2001). Brazilian Economy, The: Growth and Development: Growth and Development. Boulder: Lynne Rienner Publishers.

Barcellos, M. D., Teixeira, C. M., \& Venturini, J. C. (2014). Personal values associated with political consumption: an exploratory study with university students in Brazil. International Journal of Consumer Studies, 38(2), pp. 207-216. https://doi.org/10.1111/ijcs.12084

Brandão, M. R., Alexandre, M. L., Anez, M. E., \& Costa, B. K. (2011). Influência dos Stakeholders na adoção de estratégias de marketing verde. Revista Pretexto, 12(4). https://doi.org/10.21714/pretexto.v12i4.822

Brochet, F., Loumioti, M., \& Serafeim, G. (2013). Short-termism, Investor Clientele, and Corporate Performance. Harvard Business School Accounting \& Management Unit, 12072.

Broderick, A., Jogi, A., \& Garry, T. (2003). Tickled pink: the personal meaning of cause related marketing for customers. Journal of marketing Management, 19, (5-6), 583-610. https://doi.org/10.1080/0267257X.2003.9728227

Chen, H., \& Burns, L. D. (2006). Environmental analysis of textile products. Clothing and Textiles Research Journal, 24(3), 248-261. https://doi.org/10.1177\%2F0887302X06293065 
Chen, Y. S., \& Chang, C. H. (2013). Greenwash and green trust: The mediation effects of green consumer confusion and green perceived risk. Journal of Business Ethics, 114(3), 489-500. https://doi.org/10.1007/s10551-012-1360-0

Choi, S., \& Ng, A. (2011). Environmental and economic dimensions of sustainability and price effects on consumer responses. Journal of Business Ethics, 269-282. https://doi.org/10.1007/s10551-011-0908-8

Connelly, B. L., Ketchen Jr, D. J., \& Slater, S. F. (2011). Toward a "theoretical toolbox" for sustainability research in marketing. Journal of the Academy of Marketing Science, 39(1), 86-100. https://doi.org/10.1007/s11747-010-0199-0

Diamantopoulos, A., Schlegelmilch, B. B., Sinkovics, R. R., \& Bohlen, G. M. (2003). Can socio-demographics still play a role in profiling green consumers? A review of the evidence and an empirical investigation. Journal of Business Research, 56(6), 465-480.

https://doi.org/10.1016/S0148-2963(01)00241-7

Dickson, M. A. (1999). US consumers' knowledge of and concern with apparel sweatshops. Journal of Fashion Marketing and Management: An International Journal, Vol. 3 Iss 1 pp. 44 - 55. https://doi.org/10.1108/eb022547

Dickson, M., Waters, Y., \& López-Gydosh, D. (2012). Stakeholder Expectations for Environmental Performance within the Apparel Industry. Journal of Corporate Citizenship, 2012(45), 37-51. https://doi.org/10.9774/GLEAF.4700.2012.SP.00005

Eccles, R. G., \& Serafeim, G. (2013). A Tale of Two Stories: Sustainability and the Quarterly Earnings Call. Journal of Applied Corporate Finance, 25, 8-19. https://doi.org/10.1111/jacf.12023

Eccles, R., Ioannou, I., \& Serafeim, G. (2011). The Impact of Corporate Sustainability on Organizational Processes and Performance. Retrieved 20 jun. 2014, from Harvard business review Working Paper: http://ssrn.com/abstract=19640112013 https://doi.org/10.1287/mnsc.2014.1984

Edinger-Schons, L., Sipila, J., Sen, S., Mende, G., \& Wieseke, J. (2018). Are two reasons better than one? The role of appeal type in consumer responses to sustainable products. Journal of Consumer Psychology, 28 (4), 644-64. https://doi.org/10.1002/jcpy.1032

Freeman, R. E., Harrison, J. S., \& Wicks, A. C. (2007). Managing for stakeholders: Survival, reputation, and success. New Haven \& London: Yale University Press. Retrieved Jun 19, 2014, from http://ssrn.com/abstract=1186402 https://dx.doi.org/10.2139/ssrn.1186402

Gershoff, A. D., \& Frels, J. K. (2015). What makes it green? The role of centrality of green attributes in evaluations of the greenness of products. Journal of Marketing, 79(1), 97-110. https://doi.org/10.1509\%2Fjm.13.0303

Gonzalez-Arcos, C., Joubert, A. M., \& Scaraboto, D. (2021). "How do I carry all this now?" Understanding consumer resistance to sustainability interventions. Journal of Marketing, 85(3), 44-61. https://doi.org/10.1177\%2F0022242921992052 
Han, Tae-Im \& Stoel, L. (2017). Explaining socially responsible consumer behavior: A metaanalytic review of theory of planned behavior, Journal of International Consumer Marketing, 29 (2), 91-103. https://doi.org/10.1080/08961530.2016.1251870

Hong, Z., Wang, H., \& Yu, Y. (2018). Green product pricing with non-green product reference. Transportation Research Part E: Logistics and Transportation Review. 115, 115. https://doi.org/10.1016/j.tre.2018.03.013

International Programme on the Elimination of Child Labour (IPEC) (2013). Marking progress against child labour - Global estimates and trends (2000-2012). Geneva: International Labour Office (ILO).

Joung, S. H., Park, S. W., \& Ko, Y. J. (2014). Willingness to pay for eco-friendly products: case of cosmetics. Asia Marketing Journal, 15(4), 33-49.

Kang, J., Liu, C., \& Kim, S.-H. (2013). Environmentally sustainable textile and apparel consumption: the role of consumer knowledge, perceived consumer effectiveness and perceived personal relevance. International Journal of Consumer Studies, 37(4), 442-452. https://doi.org/10.1111/ijcs.12013

Koschate-Fischer, N., Stefan, I. V., \& Hoyer, W. D. (2012). Willingness to pay for causerelated marketing: the impact of donation amount and moderating effects. Journal of Marketing Research, 910-927. https://doi.org/10.1509\%2Fjmr.10.0511

Lopes, V. N., \& Pacagnan, M. N. (2014). Marketing verde e práticas socioambientais nas indústrias do Paraná. Revista de Administração da Universidade de São Paulo, v. 49, n. 1. https://doi.org/10.5700/rausp1135

Macnaghten, P., Grove-White, R., Jacobs, M., \& Wynne, B. (1995). Public perceptions and sustainability in Lancashire. Indicators, Institutions, Participation. A report by the Centre for the Study of Environmental Change commissioned by Lancashire County Council. http://dx.doi.org/10.13140/2.1.4038.3360

Marshall, M. N. (1996). Sampling for qualitative research. Family practice, 13(6), 522-526. https://doi.org/10.1093/fampra/13.6.522

Martinez, M. F. (2010). Variáveis explicativas da favorabilidade ambiental do consumidor: uma investigação na cidade de São Carlos. Doctorate Thesis, Escola de Administração de Empresas de São Paulo. São Paulo. http://hdl.handle.net/10438/8166

Maksudunov, A. \& Avci, M. (2020). The color of the future in marketing is green. In: A. Sekerkaya (Ed.), Contemporary Issues in Strategic Marketing (pp. 225-254). Istambul, Turkey: Istambul University Press. http://dx.doi.org/10.26650/B/SS05.2020.002.07

Moulds, J. (2015). Child labour in the fashion supply chain: Where, why and what can be done. Fonte: Theguardian: https://www.theguardian.com/sustainable-business/nginteractive/2015/jan/19/child-labour-in-the-fashion-supply-chain 
Menon, A., \& Menon, A. (1997). Enviropreneurial marketing strategy: the emergence of corporate environmentalism as market strategy. The Journal of Marketing, 51-67. https://doi.org/10.1177\%2F002224299706100105

Nittala, R. (2014). Green Consumer Behavior of the Educated Segment in India. Journal of International Consumer Marketing, 26(2), 138-152. https://doi.org/10.1080/08961530.2014.878205

Paine, L. S. (2004). Value shift: Why companies must merge social and financial imperatives to achieve superior performance. New York: McGraw Hill Professional. doi:0071427333, 9780071427333 https://doi.org/10.5465/ame.2003.10025213

Peattie, K. (1999). Trappings versus substance in the greening of marketing planning. Journal of Strategic Marketing, 7(2), 131-148. https://doi.org/10.1080/096525499346486

Peattie, K. (2001). Towards sustainability: the third age of green marketing. The Marketing Review, 2(2), 129-146. https://doi.org/10.1362/1469347012569869

Peattie, K. (2010). Green Consumption: Behavior and Norms. Annual Review of Environment and Resources, 35(1), 195-228. https://doi.org/10.1146/annurev-environ-032609-094328

Peloza, J., White, K., \& Shang, J. (2013). Good and guilt-free: the role of self-accountability influencing preferences for products with ethical attribute. Journal of Marketing, 77(1), 104-119. https://doi.org/10.1509\%2Fjm.11.0454

Pereira Heath, M. T., \& Chatzidakis, A. (2012). Blame it on marketing: consumers' views on unsustainable consumption. International Journal of Consumer Studies, 36(6), 656-667. https://doi.org/10.1111/j.1470-6431.2011.01043.x

Pinto, D. C., Nique, W. M., Añaña, E. D., \& Herter, M. M. (2011). Green consumer values: how do personal values influence environmentally responsible water consumption? International Journal of Consumer Studies, 35(2), 122-131. https://doi.org/10.1111/j.14706431.2010.00962.x

Pristl A-C., Kilian S., Mann A. (2021). When does a social norm catch the worm? Disentangling social normative influences on sustainable consumption behaviour. $J$ Consumer Behav. Special Issue Article, 1-20. https://doi.org/10.1002/ cb.1890

Ranjan, R. K. (2019). Green marketing: an exploration through qualitative research. Global Journal of Management and Business Research, [S.1.], Jan., 2249-4588. https://journalofbusiness.org/index.php/GJMBR/article/view/2989

Ribeiro, J. de A., \& Veiga, R. T. (2011). Proposição de uma escala de consumo sustentável. Revista de Administração da Universidade de São Paulo, 46(1). https://doi.org/10.5700/rausp0997

Ritter, A. M.; Borchardt, M.; Vaccaro, G. L. R.; Pereira, G. M., \& Almeida, F. (2015). Motivations for promoting the consumption of green products in an emerging country: exploring attitudes of Brazilian consumers. Journal of Cleaner Production, 106, 507-520. https://doi.org/10.1016/j.jclepro.2014.11.066 
Roberts, J. A. (1996). Green consumers in the 1990s: profile and implications for advertising. Journal of Business Research, 36(3), 217-231. https://doi.org/10.1016/01482963(95)00150-6

Rolli, C. (2014, Set 29). Marca de luxo é ligada a trabalho degradante. Retrieved from Folha de São Paulo: http://www1.folha.uol.com.br/mercado/2013/07/1317521-marca-de-luxo-eligada-a-trabalho-degradante.shtml

Sharaf, M. A., \& Perumal, S. (2018). How does green productos's price ans availability impact Malasyans' green purchasing behavior? The Journal of Social Sciences Research. 4(3), 28-34. https://ideas.repec.org/a/arp/tjssrr/2018p28-34.html

Singh, R., \& Vij, S. (2011). Dimensions of Consumers' Advertising Beliefs in India. Indian Journal of Marketing, 41(3), 21-32.

Solihin, F., Yulisetiarini, D., Wihelmina, I. D., \& Wardana, F. R. (2019). The effect of green marketing strategy on purchasing decisions: a review of previous research. International Journal of Scientific \& Technology Research, 8(12), 3662-3665. http://www.ijstr.org/finalprint/dec2019/The-Effect-Of-Green-Marketing-Strategy-On-Purchasing-Decisions-AReview-Of-Previous-Research.pdf

Spence, A., Poortinga, W., \& Pidgeon, N. (2012). The psychological distance of climate change. Risk Analysis, 32(6), 957-972. https://doi.org/10.1111/j.1539-6924.2011.01695.x

Stall-Meadows, C., \& Davey, A. (2013). Green marketing of apparel: consumers' price sensitivity to environmental marketing claims. Journal of Global Fashion Marketing, 3343. https://doi.org/10.1080/20932685.2012.753293

Straughan, R. D., \& Roberts, J. A. (1999). Environmental segmentation alternatives: a look at green consumer behavior in the new millennium. Journal of consumer marketing, 16(6), 558-575. https://doi.org/10.1108/07363769910297506

Taufique, K. M. R., Vocino, A., \& Polonsky, M. J. (2017). The influence of eco-label knowledge and trust on pro-environmental consumer behaviour in an emerging market. Journal of Strategic Marketing, 25(7), 511-29. https://doi.org/10.1080/0965254X.2016.1240219

Tseng, S.-C., \& Hung, S.-W. (2013). A framework identifying the gaps between customers' expectations and their perceptions in green products. Journal of cleaner production, 59, 174-184. https://doi.org/10.1016/j.jclepro.2013.06.050

Varadarajan, R., \& Menon, A. (1988). Cause-related marketing: A coalignment of marketing strategy and corporate philanthropy. The Journal of Marketing, 58-74. https://doi.org/10.1177\%2F002224298805200306

Varadarajan, P. Rajan (1992). Marketing's contribution to strategy: the view from a different looking glass. Journal of the Academy of Marketing Science, 20(4), 335-343. https://doi.org/10.1177\%2F0092070392204008 
Wang, W., Krishna, A., \& McFerran, B. (2016), Turning off the lights: consumers' environmental efforts depend on visible efforts of firms. Journal of Marketing Research, 54 (3), 478-94. https://doi.org/10.1509\%2Fjmr.14.0441

White, K., Habid, R., Hardisty, D. J. (2019). How to SHIFT consumer behaviors to be more sustainable: a literature review and guiding framework. Journal of Marketing, 83(3) 22-49. https://doi.org/10.1177\%2F0022242919825649

Zadeh, A. H., Zolfagharian, M. \& Hofacker, C. (2019). Customer-customer value co-creation in social media: conceptualization and antecedents, Journal of Strategic Marketing, 27(4), 283-302. https://doi.org/10.1080/0965254X.2017.1344289

Zhao, H. H., Gao, Q., Wu, Y. P., Wang, Y., \& Zhu, X. D. (2014). What affects green consumer behavior in China? A case study from Qingdao. Journal of Cleaner Production, 63, 143-151. https://doi.org/10.1016/j.jclepro.2013.05.021

Appendix 1 - Variables

\begin{tabular}{|c|c|c|c|c|}
\hline Code & Variable & Reference & Measurement method & Type \\
\hline $\mathrm{X} 1$ & $\begin{array}{l}\text { Interest for the relationship between } \\
\text { nature, people in the community and } \\
\text { apparel industry }\end{array}$ & $\begin{array}{l}\text { (Macnaghten et al., } \\
\text { 1995; Straughan \& } \\
\text { Roberts, 1999) }\end{array}$ & $\begin{array}{l}\text { Likert's scale of seven } \\
\text { positions (strongly disagree } \\
\text { and strongly agree) }\end{array}$ & Independent \\
\hline $\mathrm{X} 2$ & $\begin{array}{l}\text { Awareness of the impacts of excessive } \\
\text { consumption to the nature }\end{array}$ & $\begin{array}{l}\text { (Pereira Heath \& } \\
\text { Chatzidakis, 2012; } \\
\text { Straughan \& } \\
\text { Roberts, 1999) }\end{array}$ & $\begin{array}{l}\text { Likert's scale of seven } \\
\text { positions (strongly disagree } \\
\text { and strongly agree) }\end{array}$ & Independent \\
\hline $\mathrm{X} 3$ & $\begin{array}{l}\text { Influence of television reports, } \\
\text { showing actual results, on the price } \\
\text { sensitivity }\end{array}$ & (Connelly, et al., 2011) & $\begin{array}{l}\text { Likert's scale of seven } \\
\text { positions (strongly disagree } \\
\text { and strongly agree) }\end{array}$ & Independent \\
\hline $\mathrm{X} 4$ & $\begin{array}{l}\text { Influence of direct connection to the } \\
\text { affected people on the price sensitivity }\end{array}$ & $\begin{array}{l}\text { (Broderick, Jogi, \& } \\
\text { Garry, 2003) }\end{array}$ & $\begin{array}{l}\text { Likert's scale of seven } \\
\text { positions (strongly disagree } \\
\text { and strongly agree) }\end{array}$ & Independent \\
\hline $\mathrm{X} 5$ & $\begin{array}{l}\text { Influence of direct connection with } \\
\text { aspects of nature affected on the price } \\
\text { sensitivity }\end{array}$ & $\begin{array}{l}\text { (Broderick, Jogi, \& } \\
\text { Garry, 2003) }\end{array}$ & $\begin{array}{l}\text { Likert's scale of seven } \\
\text { positions (strongly disagree } \\
\text { and strongly agree) }\end{array}$ & Independent \\
\hline X6 & $\begin{array}{l}\text { Influence of direct advertising in the } \\
\text { media on the price sensitivity }\end{array}$ & (Connelly, et al., 2011) & $\begin{array}{l}\text { Likert's scale of seven } \\
\text { positions (strongly disagree } \\
\text { and strongly agree) }\end{array}$ & Independent \\
\hline $\mathrm{X} 7$ & $\begin{array}{l}\text { Influence of philanthropy or donation } \\
\text { on the price sensitivity }\end{array}$ & $\begin{array}{l}\text { (Varadarajan \& Menon, } \\
\text { 1988) }\end{array}$ & $\begin{array}{l}\text { Likert's scale of seven } \\
\text { positions (strongly disagree } \\
\text { and strongly agree) }\end{array}$ & Independent \\
\hline $\mathrm{X} 8$ & $\begin{array}{l}\text { Influence of sharing the responsibility } \\
\text { with the consumer on the price } \\
\text { sensitivity }\end{array}$ & $\begin{array}{l}\text { (Peloza, White, \& } \\
\text { Shang, 2013) }\end{array}$ & $\begin{array}{l}\text { Likert's scale of seven } \\
\text { positions (strongly disagree } \\
\text { and strongly agree) }\end{array}$ & Independent \\
\hline $\mathrm{X} 9$ & $\begin{array}{l}\text { Influence of appeals through social } \\
\text { networks on the price sensitivity }\end{array}$ & $\begin{array}{l}\text { (Kang, Liu, \& Kim, } \\
\text { 2013) }\end{array}$ & $\begin{array}{l}\text { Likert's scale of seven } \\
\text { positions (strongly disagree } \\
\text { and strongly agree) }\end{array}$ & Independent \\
\hline $\mathrm{X} 10$ & $\begin{array}{l}\text { Influence of appeals through articles } \\
\text { in specialized magazines on the price } \\
\text { sensitivity }\end{array}$ & $\begin{array}{l}\text { Macnaghten et al., } \\
\text { 1995; Connelly, et al., } \\
\text { 2011) } \\
\end{array}$ & $\begin{array}{l}\text { Likert's scale of seven } \\
\text { positions (strongly disagree } \\
\text { and strongly agree) }\end{array}$ & Independent \\
\hline $\mathrm{X} 11$ & $\begin{array}{l}\text { Influence of third-party assessments } \\
\text { on the price sensitivity }\end{array}$ & $\begin{array}{l}\text { (Macnaghten et al., } \\
\text { 1995; Connelly, et al., } \\
\text { 2011) }\end{array}$ & $\begin{array}{l}\text { Likert's scale of seven } \\
\text { positions (strongly disagree } \\
\text { and strongly agree) }\end{array}$ & Independent \\
\hline $\mathrm{X} 12$ & $\begin{array}{l}\text { Influence of institutional commitment } \\
\text { on the price sensitivity }\end{array}$ & $\begin{array}{l}\text { (Connelly, et al., 2011; } \\
\text { Menon \& Menon, } \\
\text { 1997) }\end{array}$ & $\begin{array}{l}\text { Likert's scale of seven } \\
\text { positions (strongly disagree } \\
\text { and strongly agree) }\end{array}$ & Independent \\
\hline Y1 & $\begin{array}{l}\text { Concern about impacts of } \\
\text { consumption behavior on nature and } \\
\text { on communities }\end{array}$ & $\begin{array}{l}\text { (Pereira Heath \& } \\
\text { Chatzidakis, 2012; } \\
\text { Straughan \& } \\
\text { Roberts,1999) }\end{array}$ & $\begin{array}{l}\text { Likert's scale of seven } \\
\text { positions (strongly disagree } \\
\text { and strongly agree) }\end{array}$ & Dependent \\
\hline AGE & Your age is: & --- & Multiple choice & Control \\
\hline GENDER & Your gender: & $-\cdots$ & Multiple choice & Control \\
\hline EDUCATION & Your formal education: & $-\cdots$ & Multiple choice & Control \\
\hline INCOME & $\begin{array}{l}\text { Your level of gross monthly income } \\
\text { is: }\end{array}$ & --- & Multiple choice & Control \\
\hline
\end{tabular}

Source: Elaborated by the authors. 
Appendix 2 - Complementary analyzes correlations

\begin{tabular}{|c|c|c|c|c|c|c|c|c|c|c|c|c|c|c|}
\hline & & Y1 & $\mathrm{X} 1$ & $\mathrm{X} 2$ & $\mathrm{X} 3$ & $\mathrm{X} 4$ & $\mathrm{X} 5$ & X6 & $\mathrm{X} 7$ & $\mathrm{X} 8$ & X9 & $\mathrm{X} 10$ & $\mathrm{X} 11$ & $\mathrm{X} 12$ \\
\hline \multirow{13}{*}{$\begin{array}{l}\text { Pearson's } \\
\text { correlation }\end{array}$} & Y1 & 1.000 & .452 & .498 & .364 & .388 & .444 & .372 & .379 & .445 & .359 & .446 & .516 & .499 \\
\hline & $\mathrm{X} 1$ & .452 & 1.000 & .744 & .378 & 209 & .324 & .336 & .307 & .341 & .341 & .353 & .319 & .350 \\
\hline & $\mathrm{X} 2$ & .498 & .744 & 1.000 & .324 & .218 & .338 & .330 & .316 & .267 & .332 & .323 & .306 & .317 \\
\hline & $\mathrm{X} 3$ & .364 & .378 & .324 & 1.000 & .614 & .608 & .709 & .554 & .565 & .523 & .632 & .590 & 643 \\
\hline & $\mathrm{X} 4$ & .388 & .209 & .218 & .614 & 1.000 & .788 & .621 & .544 & .522 & .506 & 669 & .763 & .708 \\
\hline & X5 & .444 & .324 & .338 & .608 & .788 & 1.000 & .679 & .581 & .547 & .547 & .746 & .814 & .768 \\
\hline & X6 & .372 & .336 & .330 & .709 & .621 & .679 & 1.000 & .723 & .661 & .540 & .689 & .683 & .724 \\
\hline & $\mathrm{X} 7$ & .379 & .307 & .316 & .554 & .544 & .581 & .723 & 1.000 & .656 & .605 & .638 & .645 & .653 \\
\hline & $\mathrm{X} 8$ & .445 & .341 & .267 & .565 & .522 & .547 & .661 & .656 & 1.000 & .604 & .631 & .604 & .631 \\
\hline & $\mathrm{X} 9$ & .359 & .341 & .332 & .523 & .506 & .547 & .540 & .605 & .604 & 1.000 & .662 & .590 & .539 \\
\hline & X0 & .446 & .353 & .323 & .632 & 669 & .746 & 689 & .638 & .631 & .662 & 1.000 & .798 & .778 \\
\hline & $\mathrm{X} 1$ & .516 & .319 & .306 & .590 & .763 & .814 & .683 & .645 & .604 & .590 & .798 & 1.000 & .834 \\
\hline & $\begin{array}{r}X 1 \\
2\end{array}$ & .499 & .350 & .317 & .643 & .708 & .768 & .724 & .653 & .631 & .539 & .778 & .834 & 1.000 \\
\hline
\end{tabular}

\begin{tabular}{|c|c|c|c|c|c|c|}
\hline & Model & Sum of Squares & df & Medium Square & $\mathbf{Z}$ & Sig. \\
\hline \multirow{3}{*}{3} & Regression & 207,848 & 3 & 69,283 & 39,765 & $.000^{\mathrm{d}}$ \\
\hline & Residue & 461,706 & 265 & 1,742 & & \\
\hline & Total & 669,554 & 268 & & & \\
\hline
\end{tabular}

Source: Research data. a. Dependent variable: Y1. d. Predictors: (Constant), X11, X8, ID. 


\title{
MARKETING AMBIENTAL: A ACEITAÇÃO DE PREÇO PREMIUM NA INDÚSTRIA BRASILEIRA DE VESTUÁRIO
}

\author{
Áureo Leal \\ Doutorando em Ciências Contábeis \\ Fucape Business School - FUCAPE. \\ Vitória, Espírito Santo - Brasil. \\ aureo@greensconsult.com \\ Emerson Wagner Mainardes \\ Doutor em Administração \\ Fucape Business School - FUCAPE. \\ Vitória, Espírito Santo - Brasil. \\ emerson@fucape.br \\ Lucilaine Maria Pascuci \\ Doutora em Administração \\ Universidade Federal do Espírito Santo - UFES. \\ Vitória, Espírito Santo - Brasil. \\ lucilaine.pascuci@gmail.com
}

Objetivo: Este estudo buscou identificar as variáveis que podem influenciar consumidores a pagarem um preço premium pela compra de produtos verdes na indústria do vestuário. Assume-se que a adoção de práticas sustentáveis, por parte de organizações, implica em um preço premium a ser aceito pelo consumidor decorrente dos custos associados.

Método: Com base em variáveis que consideram o binômio marketing e meio ambiente, foi desenvolvida uma pesquisa quantitativa e descritiva. Um modelo conceitual foi testado a partir de questionário aplicado a 269 respondentes. Dados foram analisados por meio da regressão linear por Mínimos Quadrados Ordinários.

Originalidade / Relevância: Discute-se questões como consumo excessivo e responsabilidade do consumidor, inovando ao introduzir a variável avaliação de terceiros, não comumente utilizada.

Resultados: Os resultados sugerem que a avaliação de terceiros e o envolvimento do consumidor como parte da solução do problema ambiental são os principais elementos que podem influenciar positivamente os consumidores a aceitarem pagar um preço premium pelo produto.

Contribuições teóricas / metodológicas: A importância da avaliação de terceiros não tem sido adotada para explicar o comportamento do consumidor em relação a produtos sustentáveis. Esta pesquisa não apenas inova ao considerar tal variável, mas também explora a importância dessa prática.

Contribuições sociais / práticas para a gestão: Para o profissional de marketing este estudo destaca a importância da legitimidade e do envolvimento dos consumidores na solução dos desafios ambientais.

\section{Como citar}

American Psychological Association (APA)

Leal, Á., Mainardes, E. W., \& Pascuci, L. M. (2021, jul./set.). Marketing ambiental: a aceitação de preço premium na indústria brasileira de vestuário. Revista Brasileira de Marketing - ReMarK, 20(3), 419-445

https://doi.org/10.5585/remark.v20i3.19495. 


\section{Introdução}

O binômio marketing e meio ambiente evoluiu em direção a um conceito de satisfazer não apenas as necessidades da geração atual, mas também, perpetuar soluções sustentáveis no longo prazo (Peattie, 2001; Ranjan, 2019; White, Habid \& Hardisty, 2019). Esse entendimento parece ser consistente com as demandas atuais por qualidade ambiental.

Os custos associados aos impactos ambientais, parte integrante do preço de produtos sustentáveis, geralmente não são considerados em relação aos produtos convencionais (Gonzalez-Arcos, Joubert \& Scaraboto, 2021; Hong, Wang \& Yu, 2018). Consequentemente, existe a percepção de que produtos sustentáveis são caros ou seus preços são irreais (Solihin, Yulisetiarini, Wihelmina \& Wardana, 2019), mas, na verdade, a competição é injusta pois os produtos convencionais estão sendo subsidiados e, portanto, irrealisticamente mais baratos (Peattie, 2001; 2010). A economia de escala também não está presente na produção verde, pelo menos no curto prazo, o que alimenta os custos e torna os preços ainda mais desfavoráveis. Portanto, é natural que um prêmio esteja embutido nos preços de produtos sustentáveis (Joung, Park \& Ko, 2014).

Os consumidores podem, eventualmente, acreditar que desempenham um papel significativo no futuro da qualidade ambiental (Sharaf \& Perumal, 2018). Todavia, para concretizar essa expectativa, eles precisam aceitar o pagamento de um preço premium por produtos ecologicamente corretos. Tal prêmio representa a internalização de custos adicionais geralmente absorvidos por toda a sociedade, no caso dos produtos convencionais (Hong et al., 2018).

Este estudo busca identificar as variáveis que podem influenciar os consumidores a pagarem um preço premium pela compra de produtos verdes na indústria do vestuário. Após uma revisão do contexto de mercado, apresenta-se as variáveis utilizadas para explicar a propensão dos consumidores a pagarem um preço premium. Também é proposto um quadro conceitual, que é testado com base em um questionário aplicado a 269 respondentes. O modelo proposto inclui marketing de causas sociais e atributos éticos, ceticismo do consumidor, proximidade dos impactos da cadeia de abastecimento sobre o consumidor, o fator de conveniência e autoavaliação da responsabilidade do consumidor, bem como aspectos sociais e normativos. Os resultados são discutidos e a conclusão aponta os elementos de marketing significativos, os quais podem influenciar os consumidores a aceitar o preço premium.

O interesse pela indústria do vestuário justifica-se por sua importância nas discussões sobre sustentabilidade socioambiental (Edinger-Schons, Sipila, Sen, Mende \& Wieseke, 2018; 
Maksudunov \& Avci, 2020). A existência de oficinas de produção onde os trabalhadores são contratados com salários abaixo do nível de mercado, longas jornadas e péssimas condições de trabalho e que costumam usar trabalhadores ilegais - mesmo nos Estados Unidos - tornou este tema um interesse público devido à clara necessidade de coibir tais práticas (Dickson, 1999). No Brasil, a loja espanhola Zara, que atua globalmente e é vista como um fenômeno no mercado da moda, admitiu ao final de um procedimento de fiscalização do Ministério do Trabalho e Emprego (Rolli, 2014), em 2011, que tinha mão-de-obra escrava na cadeia de abastecimento de seus produtos.

A revisão da literatura confirma a existência de estudos abordando conceito de marketing verde, segmentação de mercado e caracterização do consumidor verde, bem como sensibilidade do preço aos apelos do marketing ambiental (Amoako, Dzogbenuku \& Abubakari, 2020; Dickson, Waters \& López-Gydosh, 2012; Joung et al, 2014; Kang, Liu, \& Kim, 2013; White et al., 2019). No entanto, não se identificou nenhuma pesquisa que abordasse a relação entre consumidores de produtos de vestuário e esforços de vendas, considerando o mercado brasileiro (Brandão, Alexander, Anez, \& Costa, 2011; Choi \& Ng, 2011; Lopes \& Pacagnan, 2014; Martinez, 2010; Pereira, Heath \& Chatzidakis, 2012; Ribeiro \& Veiga, 2011; Sharaf \& Perumal, 2018; Stall-Meadows \& Davey, 2013).

Diante desse contexto, esta pesquisa traz algumas contribuições relevantes. Primeiro, discute-se a sensibilidade à preço aos apelos do marketing ambiental no domínio dos produtos têxteis e de vestuário em uma economia emergente, caracterizada pela rápida urbanização e crescimento econômico. Nessas circunstâncias, identifica-se a falta de conscientização pública sobre a relação entre a indústria e a degradação ambiental (Chan \& Lau, 2000). Como uma segunda contribuição, o estudo modela a propensão dos consumidores a pagarem um preço premium, utilizando uma variável explicativa adicional: avaliação de terceiros. Essa variável adicional amplia a discussão e apoia a tendência internacional de integração de relatórios financeiros anuais e relatórios de sustentabilidade propostos pelo Sustainability Accounting Standards Board (SASB), pelo International Integrated Reporting Council (IIRC) e, ainda, pela Global Reporting Initiative (GRI). 


\section{Fundamentação Teórica}

\subsection{Contexto econômico}

A maioria das organizações desenvolve algum tipo de programa de sustentabilidade, todavia, o desafio parece estar em evoluir de iniciativas isoladas para uma estratégia corporativa de fato (Eccles, Ioannou \& Serafeim, 2011; Eccles \& Serafeim, 2013). Essa evolução é lenta e requer uma combinação de mudanças relacionadas à legislação, impostos, ação do consumidor, inovação e liderança corporativa (Gonzalez-Arcos et al., 2021; Peattie, 2010).

Organizações que avaliam positivamente o valor agregado de iniciativas socioambientais podem fazê-lo de diferentes maneiras. Pode-se, por exemplo, se concentrar na avaliação do desempenho financeiro de longo prazo (Brochet, Loumioti \& Serafeim, 2013), dando mais atenção ao impacto dessa operação no meio ambiente e nas comunidades (Paine, 2004); estabelecer padrões éticos mais elevados (Paine, 2004); e, ainda, implementar sistemas sofisticados de gerenciamento das partes interessadas (Freeman, Harrison \& Wicks, 2007). Tradicionalmente, os custos adicionais decorrentes de tais decisões seriam absorvidos pela sociedade, e a internalização desses custos seria necessariamente compensada pelo valor econômico agregado (Eccles et al., 2011).

No que diz respeito à cadeia têxtil e do vestuário, em particular, eles têm destaque pelo seu potencial impacto no meio ambiente. $\mathrm{O}$ impacto ambiental da produção têxtil é significativo e se estende ao longo do ciclo de vida do produto têxtil: matérias-primas, produção, limpeza e descarte (Chen \& Burns, 2006). Os desafios incluem a capacidade de renovação de matériasprimas, a toxicidade dos produtos químicos e pesticidas utilizados nos processos de fabricação e limpeza e o elevadíssimo consumo de água, além de aspectos relacionados à reciclagem e biodegradabilidade (Kang et al., 2013).

De acordo com o relatório do Programa Internacional para a Eliminação do Trabalho Infantil (2013), embora as estimativas sugiram que o trabalho infantil diminuiu 30\% entre 2000 e 2012, as crianças que trabalham abaixo da idade mínima exigida ou em seu detrimento ainda representavam, à época, $11 \%$ das crianças do mundo. Muitas dessas crianças trabalham na cadeia de suprimentos da moda, fabricando os têxteis e as peças de vestuário para atender à demanda de consumidores na Europa, Estados Unidos, entre outros (Molds, 2015). Assim, o rótulo ambientalmente responsável raramente pode ser aplicado de forma adequada à produtos têxteis (Chen \& Burns, 2006).

O Brasil, por sua vez, pode ser considerado um mercado importante devido à sua presença significativa na economia global, capacidade industrial diversificada e grande 
população de influências europeias e africanas (Baer, 2001). Apesar da inclusão de 40 milhões de pessoas na classe média brasileira entre 2003 e 2011, o Brasil ainda tem enfrentado grandes desafios sociais, especialmente, em termos de desigualdade na distribuição da riqueza. Consequentemente, tem sido crescente o uso de recursos naturais e, também, o esgotamento ambiental (Barcellos, Teixeira \& Venturini, 2014).

\subsection{Marketing de causas sociais}

Existem diversas práticas que podem ser adotadas por organizações interessadas em atuar - ou fortalecer sua atuação - de forma socioambiental. Uma prática amplamente adotada é a introdução de um compromisso ambiental como uma filosofia corporativa e institucional em oposição a uma abordagem tática e administrativa (Han \& Stoel, 2017; Menon \& Menon, 1997; Varadarajan, 1992). Uma ilustração dessa prática é o compromisso corporativo de contribuir com um valor - doação - para uma determinada causa condicionado a uma decisão favorável do consumidor em adquirir os produtos da corporação. Assim, a doação pode atender simultaneamente aos objetivos organizacionais e individuais (Varadarajan \& Menon, 1988). Como resultado, pode existir uma relação positiva entre doações corporativas e comportamento favorável do consumidor em relação aos produtos da empresa (Koschate-Fischer, Stefan \& Hoyer, 2012).

Uma forma semelhante de expressar esse compromisso corporativo e institucional é promover campanhas baseadas em atributos éticos. Se o esforço de marketing é despertar os consumidores para suas próprias responsabilidades, os consumidores podem avaliar seu medo de culpa futura, o que pode levar à decisão de comprar um produto que amenize esse sentimento (Peloza, White \& Shang, 2013).

\subsection{Consumidores céticos}

A resposta dos consumidores aos apelos de marketing, em geral, é função da crença de que eles têm o poder de influenciar positivamente os resultados reais no mundo real (Straughan \& Roberts, 1999; Han \& Stoel, 2017; Edinger-Schons, Sipila, Sen, Mende \& Wieseke, 2018). A capacidade de influenciar a melhoria das condições ambientais percebidas pelo consumidor está altamente correlacionada com o comportamento do consumidor com consciência ambiental e é, por si só, o mais forte construtor desse comportamento. Portanto, os consumidores aceitam o pagamento de um valor adicional apenas se os produtos verdes tiverem características que possam ser verificadas (Joung et al., 2014; Roberts, 1996; Taufique, Vocino \& Polonsky, 2017). 
Esse mesmo entendimento foi apoiado por Singh e Vij (2011), que identificaram consumidores que acreditavam que a publicidade poderia enganar e manipular os indivíduos para comprar em excesso e até mesmo comprar coisas desnecessárias. A pesquisa realizada por Stall-Meadows e Davey (2013) sobre a indústria do vestuário também destacou o valor da credibilidade das afirmações de marketing. Eles devem ser precisos e verificados para ganhar legitimidade.

O governo e as organizações são comumente vistos como parte do sistema com uma tendência a interesses próprios e objetivos de curto prazo (Macnaghten et al, 1995). Mesmo as pessoas que não estão familiarizadas com a ideia de sustentabilidade a reconhecem, positivamente, em termos de seus valores e prioridades. No entanto, eles são muito céticos quanto à capacidade do governo e das organizações de promoverem, genuinamente, a sustentabilidade (Macnaghten et al, 1995).

Para minimizar o cepticismo, promover a integração progressiva das práticas ambientais e sociais nos modelos de negócio já representa uma iniciativa nova e relevante. Essa é uma mudança importante que pode reduzir a assimetria de informação, além de facilitar a avaliação da autenticidade das organizações, por parte dos consumidores (Connelly et al., 2011).

Existem diversas práticas que podem ser adotadas por organizações interessadas em atuar - ou fortalecer sua atuação - de maneira socioambiental. Uma prática amplamente adotada é adotar um compromisso ambiental como uma filosofia corporativa e institucional, ao invés de uma abordagem tática e administrativa (Han \& Stoel, 2017; Menon \& Menon, 1997; Varadarajan, 1992). Uma ilustração dessa prática seria o compromisso corporativo de contribuir com um valor - doação - para determinada causa, condicionado a decisão favorável do consumidor em adquirir os seus produtos. Assim, a doação poderia atender, simultaneamente, os objetivos organizacionais e individuais (Varadarajan \& Menon, 1988). Como resultado, temse uma relação positiva entre doações corporativas e comportamento favorável do consumidor em relação aos produtos da empresa (Koschate-Fischer, Stefan \& Hoyer, 2012).

Uma forma semelhante de expressar esse compromisso corporativo e institucional é promover campanhas baseadas em atributos éticos. Se o esforço de marketing despertar os consumidores para suas próprias responsabilidades, eles podem considerar sentir potencial culpa futura, o que pode incentiva-los a comprar um produto que amenize tal sentimento (Peloza, White \& Shang, 2013). 


\subsection{Ceticismo dos consumidores}

A resposta dos consumidores aos apelos de marketing, em geral, é função da crença de que eles detêm o poder de influenciar, positivamente, os resultados do mundo real (EdingerSchons, Sipila, Sen, Mende \& Wieseke, 2018; Han \& Stoel, 2017; Straughan \& Roberts, 1999). A capacidade de influenciar a melhoria das condições ambientais está altamente correlacionada com o comportamento e consciência ambiental do consumidor que é, por si só, o mais forte construtor desse comportamento. Portanto, os consumidores aceitariam pagar um valor adicional em situações onde os produtos verdes apresentam características que possam ser verificadas (Joung et al, 2014; Roberts, 1996; Taufique, Vocino \& Polonsky, 2017).

Esse mesmo entendimento foi apoiado por Singh e Vij (2011) que identificaram consumidores que acreditavam que a publicidade poderia enganar e manipular os indivíduos para comprarem em excesso e, até mesmo, fazer compras desnecessárias. A pesquisa realizada por Stall-Meadows e Davey (2013) sobre a indústria do vestuário também destacou o valor da credibilidade das afirmações de marketing. Tais afirmações devem ser precisas e verificadas para ganharem legitimidade.

Governo e organizações são comumente vistos como parte de um sistema com tendência à interesses próprios e objetivos de curto prazo (Macnaghten et al, 1995). Mesmo as pessoas que não estão familiarizadas com a ideia de sustentabilidade a reconhecem, positivamente, em termos de seus valores e prioridades. No entanto, eles são muito céticos quanto à capacidade do governo e das organizações de promoverem, genuinamente, a sustentabilidade (Macnaghten et al, 1995).

Para minimizar o ceticismo, promover uma integração progressiva das práticas ambientais e sociais nos modelos de negócio já representaria uma iniciativa nova e relevante. Trata-se de uma mudança importante que pode reduzir a assimetria de informação, além de facilitar aos consumidores a avaliação da autenticidade das práticas organizacionais, neste assunto (Connelly et al, 2011).

\subsection{Proximidade com o consumidor}

Em campanhas de marketing relacionadas à uma causa típica, um aspecto relevante é o envolvimento pessoal ou emocional dos consumidores com a causa em questão (Han \& Stoel, 2017). Uma pesquisa de Brodericki, Jogi e Garry (2003), considerando uma campanha de conscientização sobre o câncer de mama, mostrou a importância do tema para algumas consumidoras seja porque o câncer de mama pode afetá-las diretamente ou pelo fato de alguém 
próximo delas já ter sido afetado por esta doença. A pesquisa destes autores também identificou um sentimento de solidariedade, possivelmente, devido a relação mais próxima com o tema o qual influenciou positivamente os resultados da campanha.

Segundo Diamantopoulos, Schlegelmilch, Sinkovics e Bohlen (2003) o comportamento do consumidor em relação às questões ambientais é função de fatores situacionais, como a exposição direta a quaisquer efeitos negativos decorrentes da atividade da organização. Esta pesquisa corrobora com a teoria da distância psicológica do consumidor (Spence, Poortinga \& Pidgeon, 2012) segundo a qual os consumidores tendem a ser mais sensíveis a questões mais próximas de sua realidade. No entanto, diferentes consumidores podem manifestar comportamento de maneiras diversas.

\subsection{Conveniência}

Outro aspecto importante em relação ao comportamento do consumidor é reconhecer a diferença entre conveniência e consistência nas suas práticas de consumo. McDonald e Oates (2006) testaram empiricamente e confirmaram a previsão teórica de Peattie (1999) a respeito do processo de compra de um produto verde. A literatura sugere a ausência de um consumidor verde, mas, a existência de compras verdes. Nesta perspectiva, os consumidores agem de forma diferente dependendo das circunstâncias. Ou seja, os consumidores agem de maneira conveniente, mas inconsistente; ao considerarem o esforço necessário para uma compra verde, eles têm que aceitar certas características do que pretendem comprar, incluindo o preço e o resultado que essa decisão produzirá em termos ambientais. Portanto, os consumidores ponderam o seu nível de comprometimento em relação ao nível de confiança que possuem de que a compra produzirá resultados úteis.

A variável conveniência está relacionada as percepções de eficácia, por parte dos consumidores. É a percepção dos consumidores com relação a quanto seu consumo favorecerá, positivamente, ou causará menos danos ao meio ambiente (Akehurst, Afonso \& Gonçalves, 2012; Antonetti \& Maklan, 2014; Chen \& Chang, 2013; Gershoff \& Frels, 2015; Roberts, 1996; Straughan \& Roberts, 1999; White et al, 2019).

Segundo pesquisa de Pereira, Heath e Chatzidakis (2012), o consumo excessivo pode ser outro aspecto relevante para a análise do comportamento dos consumidores de produtos verdes. Os consumidores, em geral, percebem o nível de consumo excessivo da sociedade em que vivem, todavia, atribuem total responsabilidade aos sistemas de marketing das organizações. A negação de responsabilidade ocorre quando se atribui o problema à terceiros, 
incluindo o sistema educacional ou a sociedade, em geral; culpar o sistema de marketing representa uma forma de eliminar a responsabilidade pessoal (Pereira, Heath \& Chatzidakis, 2012; Solihin et al., 2019).

\subsection{Aspectos normativos e sociais}

A mídia social mudou significativamente a maneira como consumidores e produtores interagem. Tornou possível, por exemplo, a troca de informações entre uma infinidade de consumidores geograficamente dispersos. A intensa troca de informações pode atingir e influenciar as pessoas, permitindo que clientes integrem recursos ao interagirem entre si e, assim, co-criem e os utilizem durante o consumo (Zadeh, Zolfagharian \& Hofacker, 2019).

Embora existam algumas controvérsias entre pesquisadores sobre a relação entre aspectos normativos, sociais e atitudes favoráveis ao meio ambiente, Pristl, Kilian e Mann (2021) reconheceram que o consumo sustentável se destaca, entre outros motivos, devido à pressão social. Mesmo assim, estes autores destacaram que o comportamento pró-ambiental e o consumo sustentável podem ser efetivamente incentivados por aspectos normativos e sociais.

No que diz respeito à indústria do vestuário Kang et al. (2013) identificaram que normas sociais podem pressionar, significativamente, as pessoas a comprarem roupas sustentáveis. Nesse sentido, tanto redes sociais quanto mídias sociais podem desempenhar um importante papel normativo e social.

\subsection{Modelo proposto}

A crença de que a qualidade ambiental pode ser melhorada pelo comportamento do consumidor está diretamente associada aos motivadores internos e externos dos consumidores. Os motivadores externos incluem mensagens de marketing que têm como objetivo melhorar a conscientização das fraquezas ambientais, bem como a publicidade de produtos verdes, o compromisso institucional, o marketing relacionado a causas, campanhas educacionais patrocinadas pelo governo, além da disponibilidade de centros de reciclagem e de coleta (Mainardes, Yeh \& Leal, 2017).

Para efeito desta pesquisa e, com base nos estudos supracitados, são propostas quatro variáveis para identificar fontes de informação disponíveis aos consumidores, duas variáveis para avaliar a proximidade destes em relação aos problemas causados pela degradação ambiental e, ainda, quatro estratégias de marketing distintas (Figura 1). 
Os motivadores internos abrangem todas os constructos que estão sob controle do consumidor e refletem atitudes e preocupações individuais. Duas variáveis foram propostas para identificar motivadores pessoais e individuais: atitude verde e preocupação ambiental (Figura 1). Por fim, como variável dependente, o comportamento verde é identificado por meio da variável Y1, ou seja, a preocupação do consumidor com os impactos do comportamento de consumo na natureza e nas comunidades.

Figura 1 - Modelo proposto

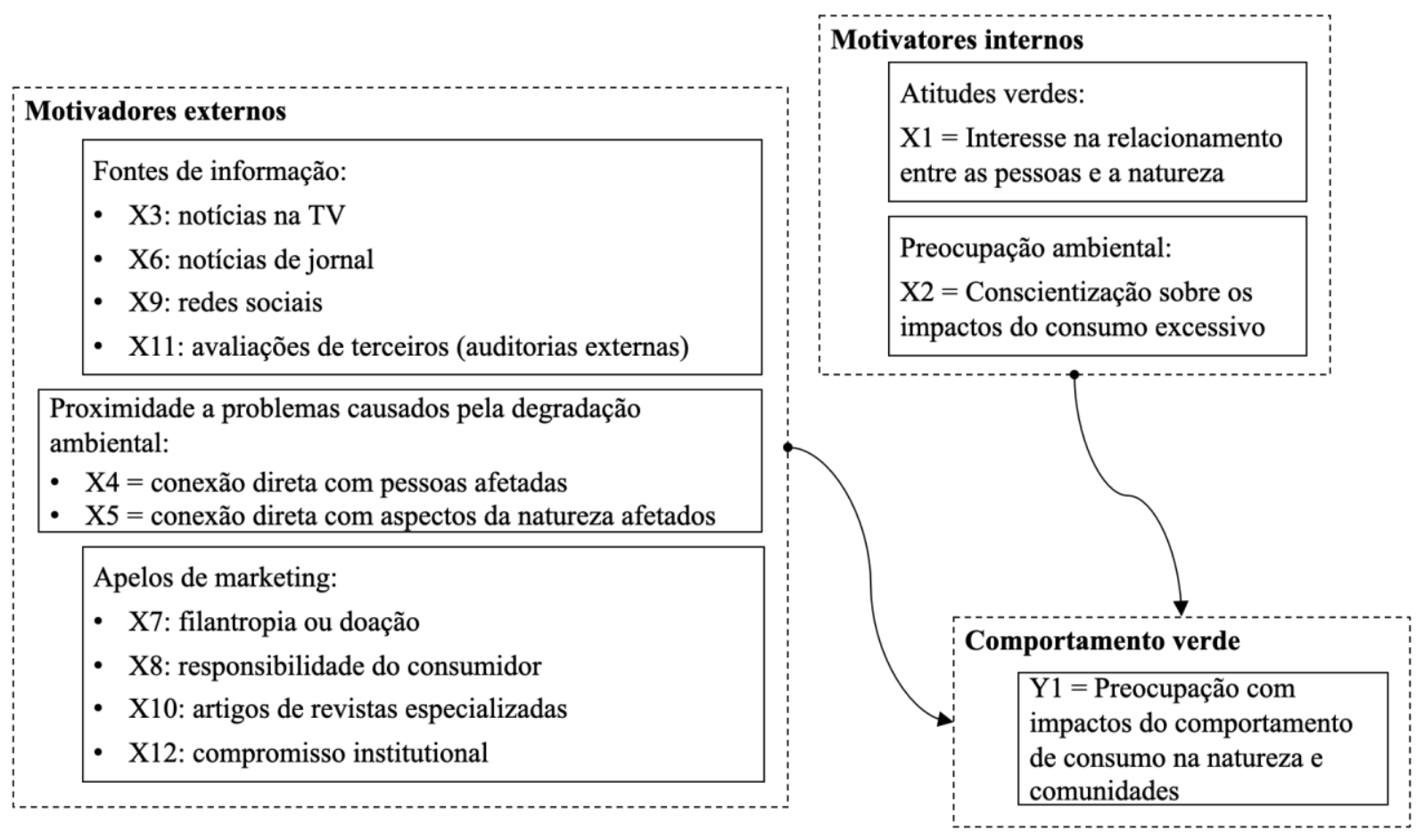

Fonte: Os autores.

\section{Métodos}

Com o objetivo de identificar as variáveis que podem influenciar os consumidores a pagarem um preço premium pela compra de produtos verdes na indústria do vestuário, desenvolveu-se uma pesquisa quantitativa e descritiva. O modelo proposto foi desenvolvido em consonância com a literatura, uma vez que as variáveis adotadas foram extraídas de diferentes estudos (ver Apêndice 1).

A população foi representada por consumidores de vestuário em geral, roupas e acessórios, partindo do pressuposto de que os respondentes compram roupas rotineiramente. A amostra pode ser caracterizada como não probabilística por não buscar respondentes de um segmento específico relacionado à causa ambiental ou, mesmo, que atuem em um setor com 
especial interesse no assunto. Com base nessas características, a amostra se mostrou adequada ao objetivo deste estudo, sem evidências de viés. No entanto, não há evidências de que a amostra seja representativa da população.

As pessoas foram selecionadas, aleatoriamente, à medida que aceitavam os convites postados nas redes sociais. Os questionários foram enviados para 1.500 pessoas que manifestaram interesse em participar da pesquisa. Destes interessados obteve-se 269 respostas completas, representando uma taxa de retorno de $18 \%$.

O questionário foi elaborado com base em diversos estudos relacionados ao binômio marketing e meio ambiente (Broderick et al, 2003; Connelly et al, 2011; Kang et al, 2013; Macnaghten et al, 1995; Menon \& Menon, 1997; Peloza et al, 2013, Pereira, Heath \& Chatzidakis, 2012; Straughan \& Roberts, 1999; Varadarajan \& Menon, 1988). Adotou-se um questionário com 17 questões em escala de Likert de sete posições (de "discordo totalmente" a "concordo totalmente") com 13 questões representativas das variáveis a serem analisadas. O questionário também incluiu quatro questões de múltipla escolha sobre caracterização demográfica, as quais foram utilizadas como controle. As variáveis de controle foram: idade, gênero, escolaridade formal e nível de renda do consumidor.

O questionário foi validado em duas etapas. O conteúdo foi validado por dois especialistas no assunto e, na sequência, foi realizada uma validação de face com pré-teste com 12 pessoas pertencentes ao público-alvo do estudo. O questionário foi aplicado no período de 15 de setembro a 17 de outubro de 2016, por meio do Google Forms. Os dados coletados foram analisados com uso do SPSS 22. O modelo estatístico adotado foi a regressão linear por Mínimos Quadrados Ordinários (MQO).

Considerando que uma pergunta direta sobre a intenção do entrevistado em pagar um preço premium poderia enviesar o resultado adotou-se como proxy a autoavaliação do entrevistado sobre seu comportamento e atitude em relação aos impactos socioambientais. $\mathrm{Ou}$ seja, assumiu-se que os consumidores que se definem como ambientalmente responsáveis têm maior probabilidade de aceitar pagar um preço premium pela sustentabilidade.

\section{Análise}

A amostra, com 269 respostas válidas (Marshall, 1996), pode ser demograficamente caracterizada como predominantemente masculina $(58,7 \%)$, com curso superior $(98,5 \%)$, acima de 30 anos $(82,5 \%)$ e com renda relativamente elevada $(71,7 \%)$, conforme apresentado na Tabela 1. 
Tabela 1 - Demografia da amostra

\begin{tabular}{|l|l|l|}
\hline Gênero & Frequência & $\%$ \\
\hline Feminino & 111 & 41,3 \\
\hline Masculino & 158 & 58,7 \\
\hline Total & 269 & 100,0 \\
\hline
\end{tabular}

\begin{tabular}{|l|l|l|}
\hline Escolaridade & Frequência & $\%$ \\
\hline Ensino médio & 4 & 1,5 \\
\hline Ensino superior & 265 & 98,5 \\
\hline Total & 269 & 100,0 \\
\hline
\end{tabular}

\begin{tabular}{|l|l|l|}
\hline Idade & Frequência & $\%$ \\
\hline Abaixo de 30 anos & 47 & 17,5 \\
\hline Entre 30 e 40 anos & 77 & 28,6 \\
\hline Acima de 40 anos & 145 & 53,9 \\
\hline Total & 269 & 100,0 \\
\hline
\end{tabular}

\begin{tabular}{|c|c|c|}
\hline Salário mensal & Frequência & $\%$ \\
\hline $\begin{array}{l}\text { Menor } \\
1.000\end{array}$ & 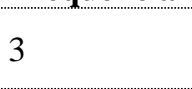 & 1,1 \\
\hline $\begin{array}{l}\mathrm{R} \$ 1.000-\mathrm{R} \$ \\
5.000\end{array}$ & 73 & 27,1 \\
\hline $\begin{array}{l}\text { Acima de } \mathrm{R} \$ \\
5.000\end{array}$ & 193 & 71,7 \\
\hline Total & 269 & 100,0 \\
\hline
\end{tabular}

Fonte: Elaborado pelos autores.

\subsection{Estatística Descritiva}

Todas as 269 respostas pontuaram, pelo menos uma vez, o valor mínimo de 1 e o máximo de 7. Conforme apresentado na Tabela 2, a estatística descritiva apresentou médias no intervalo de 4,1 a 5,2 (o centro da escala é 4), desvios-padrão variando de 1,4 a 1,8 e coeficientes de variação de $29 \%$ a 43\%. As variáveis de X1 a X12 são variáveis independentes e Y1 é a variável dependente.

Tabela 2 - Descrição das variáveis e resultados

\begin{tabular}{|c|c|c|c|c|c|}
\hline & ariáveis Dependente e Independente & Referência & Mé & $\begin{array}{l}\text { Desvio } \\
\text { Padrão }\end{array}$ & $\begin{array}{l}\text { M/DP } \\
(\mathrm{CoV})\end{array}$ \\
\hline $\mathrm{X} 1$ & $\begin{array}{l}\text { Interesse na relação entre a natureza, } \\
\text { pessoas da comunidade e indústria de } \\
\text { vestuário }\end{array}$ & $\begin{array}{l}\text { (Macnaghten et al., 1995; } \\
\text { Straughan \& Roberts, 1999) }\end{array}$ & 4,2 & 1,7 & $41 \%$ \\
\hline $\mathrm{X} 2$ & $\begin{array}{l}\text { Conscientização dos impactos do consumo } \\
\text { excessivo na natureza }\end{array}$ & $\begin{array}{c}\text { (Pereira Heath \& Chatzidakis, } \\
\text { 2012; Straughan \& } \\
\text { Roberts, 1999) }\end{array}$ & 4,1 & 1,8 & $43 \%$ \\
\hline X3 & $\begin{array}{l}\text { Influência na sensibilidade ao preço de } \\
\text { reportagens de TV mostrando resultados } \\
\text { reais }\end{array}$ & (Connelly et al., 2011) & 4,7 & 1,5 & $32 \%$ \\
\hline X4 & $\begin{array}{l}\text { Influência na sensibilidade ao preço de } \\
\text { uma conexão direta com pessoas afetadas }\end{array}$ & (Broderick et al., 2003) & 5,1 & 1,5 & $30 \%$ \\
\hline $\mathrm{X} 5$ & $\begin{array}{c}\text { Influência na sensibilidade ao preço de } \\
\text { conexão direta com aspectos da natureza } \\
\text { afetados }\end{array}$ & (Broderick et al., 2003) & 5,0 & 1,5 & $30 \%$ \\
\hline
\end{tabular}




\begin{tabular}{|c|c|c|c|c|c|}
\hline & ariáveis Dependente e Independente & Referência & $\begin{array}{l}\text { Mé } \\
\text { dia }\end{array}$ & $\begin{array}{l}\text { Desvio } \\
\text { Padrão } \\
\text { (SD) }\end{array}$ & $\begin{array}{l}\mathrm{M} / \mathrm{DP} \\
(\mathrm{CoV})\end{array}$ \\
\hline $\mathrm{X} 6$ & $\begin{array}{l}\text { Influência na sensibilidade ao preço da } \\
\text { publicidade direta na mídia }\end{array}$ & (Connelly et al., 2011) & 4,6 & 1,4 & $31 \%$ \\
\hline $\mathrm{X} 7$ & $\begin{array}{l}\text { Influência na sensibilidade ao preço da } \\
\text { filantropia ou doação }\end{array}$ & (Varadarajan \& Menon, 1988) & 4,7 & 1,5 & $32 \%$ \\
\hline $\mathrm{X} 8$ & $\begin{array}{l}\text { Influência na sensibilidade ao preço de } \\
\text { compartilhar a responsabilidade com o } \\
\text { consumidor }\end{array}$ & (Peloza et al., 2013) & 4,3 & 1,5 & $35 \%$ \\
\hline X9 & $\begin{array}{l}\text { Influência na sensibilidade ao preço de } \\
\text { recursos por meio de redes sociais }\end{array}$ & (Kang et al., 2013) & 4,3 & 1,6 & $37 \%$ \\
\hline $\mathrm{X} 10$ & $\begin{array}{l}\text { Influência na sensibilidade ao preço de } \\
\text { recursos por meio de artigos em revistas } \\
\text { especializadas }\end{array}$ & $\begin{array}{l}\text { (Macnaghten et al., 1995; } \\
\text { Connelly et al., 2011) }\end{array}$ & 4,8 & 1,4 & $30 \%$ \\
\hline $\mathrm{X} 11$ & $\begin{array}{l}\text { Influência na sensibilidade ao preço de } \\
\text { avaliações de terceiros }\end{array}$ & $\begin{array}{l}\text { (Macnaghten et al., 1995; } \\
\text { Connelly et al., 2011) }\end{array}$ & 5,2 & 1,5 & $29 \%$ \\
\hline $\mathrm{X} 12$ & $\begin{array}{l}\text { Influência na sensibilidade ao preço do } \\
\text { compromisso institucional }\end{array}$ & $\begin{array}{c}\text { (Connelly et al., 2011; Menon } \\
\text { \& Menon, 1997) }\end{array}$ & 5,0 & 1,5 & $31 \%$ \\
\hline Y1 & $\begin{array}{l}\text { Preocupação com os impactos do } \\
\text { comportamento de consumo na natureza e } \\
\text { nas comunidades }\end{array}$ & $\begin{array}{l}\text { (Pereira Heath \& Chatzidakis, } \\
\text { 2012; Straughan \& } \\
\text { Roberts, 1999) }\end{array}$ & 4,7 & 1,6 & $34 \%$ \\
\hline
\end{tabular}

Fonte: Elaborado pelos autores.

\subsection{Inferência}

Utilizando uma variável para representar o comportamento ambientalmente responsável, o modelo de regressão com a variável dependente Y1 (consumidor preocupado com os impactos do comportamento de consumo na natureza e nas pessoas da comunidade) apresentou um $\mathrm{R}^{2}$ Ajustado de 0,303 . Para o $\mathrm{R}^{2}$ ajustado, um valor de 0,20 ou superior indica uma linearidade aceitável nas relações testadas (Azasu, 2009). Para efeito deste estudo, o $\mathrm{R}^{2}$ ajustado foi utilizado apenas para verificar a linearidade do modelo. Além disso, em levantamentos psicométricos, resultados de $\mathrm{R}^{2}$ ajustado acima de $25 \%$ são considerados bons devido à complexidade do comportamento humano (Chen \& Chang, 2013).

A partir desse resultado, a questão Y1 foi usada como proxy para inferir a disposição dos consumidores em pagar um preço premium por produtos sustentáveis e se tornou o foco de análises posteriores. Um modelo de regressão linear múltipla, resolvido por MQO, com nível de significância de 5\%, foi utilizado para identificar as variáveis explicativas, estatisticamente 
significativas, para explicar a propensão do consumidor a pagar um preço premium por produtos sustentáveis. O modelo é representado pela Equação 1.

$$
Y 1=\alpha+\beta 1 X 1+\beta 2 X 2+\cdots+\beta 12 X 12+\text { controles }+\varepsilon
$$

As variáveis explicativas foram previamente definidas (ver Tabela 2). Os resultados da regressão, com R2 ajustado igual a 30,3\%, estão apresentados na Tabela 3 e na Tabela 4. A validade da amostra também foi verificada. Foram realizados testes de outliers, de multicolinearidade, de aleatoriedade, de normalidade da distribuição dos resíduos, de homocedasticidade e de variância. Como não foram identificados problemas, a amostra foi considerada válida. Também se verificou a inexistência de variáveis que agrupassem as variáveis testadas. Os resultados das correlações entre as variáveis e o teste ANOVA do modelo são apresentados no Apêndice 2.

As variáveis explicativas para as quais a hipótese nula é rejeitada $\left(H_{0}=0\right)$ são: "responsabilidade compartilhada com o consumidor" (X8) e "avaliação de terceiros" (X11), ambas com p-valor menor que 0,05. Portanto, a capacidade do discurso de marketing de compartilhar a responsabilidade com os consumidores para resolver os desafios ambientais e a validade assegurada por avaliações de terceiros foram as únicas duas variáveis explicativas da propensão dos consumidores a pagar um preço premium por produtos de vestuário verdes, seguindo a amostra. As variáveis de controle incluídas no modelo foram idade, gênero, nível de educação formal e nível de renda do consumidor. Destas variáveis de controle, apenas a idade foi considerada significativa.

Tabela 3 - Resumo do modelo

\begin{tabular}{|c|c|c|c|c|c|c|c|c|c|c|}
\hline \multirow[b]{2}{*}{ Modelo } & \multirow[b]{2}{*}{$\mathbf{R}$} & \multirow[b]{2}{*}{$\begin{array}{c}\mathbf{R} \\
\text { quadrado }\end{array}$} & \multirow{2}{*}{$\begin{array}{c}\mathbf{R} \\
\text { quadrad } \\
\mathbf{o} \\
\text { ajustado }\end{array}$} & \multirow[b]{2}{*}{$\begin{array}{c}\text { Erro } \\
\text { padrão }\end{array}$} & \multicolumn{5}{|c|}{ Estatísticas de mudança } & \multirow[b]{2}{*}{ Durbin-Watson } \\
\hline & & & & & $\begin{array}{c}\text { Alteração } \\
\text { de } R \\
\text { quadrado }\end{array}$ & $\begin{array}{l}\text { Alteração } \\
\qquad \mathbf{F}\end{array}$ & df1 & df2 & $\begin{array}{c}\text { Sig. } \\
\text { Alteração F }\end{array}$ & \\
\hline 3 &, $557^{\mathrm{c}}$ &, 310 & ,303 & 1,31996 & ,016 & 6,318 & 1 & 265 & ,013 & 1,928 \\
\hline
\end{tabular}

Fonte: Dados da pesquisa. a. Preditores: (Constante), X11, X8, Idade. b. Variável dependente: Y1.

Tabela 4 - Coeficientes ${ }^{\mathrm{a}}$

\begin{tabular}{|c|c|c|c|c|c|c|c|c|c|c|c|c|c|}
\hline \multirow{2}{*}{\multicolumn{2}{|c|}{ Modelo }} & \multicolumn{2}{|c|}{$\begin{array}{c}\text { Coeficientes não } \\
\text { padronizados }\end{array}$} & \multirow{2}{*}{$\begin{array}{c}\begin{array}{c}\text { Coeficientes } \\
\text { padronizados }\end{array} \\
\text { Beta }\end{array}$} & \multirow{2}{*}{$\mathbf{T}$} & \multirow{2}{*}{ Sig. } & \multicolumn{2}{|c|}{$\begin{array}{c}95,0 \% \text { Intervalo de } \\
\text { Confiança B }\end{array}$} & \multicolumn{3}{|c|}{ Correlações } & \multicolumn{2}{|c|}{$\begin{array}{c}\text { Estatísticas de } \\
\text { colinearidade }\end{array}$} \\
\hline & & B & Erro & & & & Limite & Limite & Ordem & Parcial & Parte & Tolerância & VIF \\
\hline \multirow{4}{*}{3} & (Const) & 1.070 &, 370 & & 2,893 & ,004 &, 342 & 1,799 & & & & & \\
\hline & & ,386 & ,066 &, 374 & 5,809 & ,000 &, 255 &, 517 &, 516 & ,336 & ,296 & 629 & 1,590 \\
\hline & $\mathrm{X} 8$ &, 222 & ,068 &, 210 & 3,283 & ,001 & ,089 & ,355 & ,445 & , 198 & ,167 & ,635 & 1,576 \\
\hline & Idade & ,267 &, 106 &, 129 & 2,514 &, 013 &, 058 &, 477 &, 187 &, 153 &, 128 & ,986 & 1,014 \\
\hline
\end{tabular}


Fonte: Dados da pesquisa. a. Variável dependente: Y1.

\section{Resultados e discussão}

Considerando que o centro da escala é 4 e os resultados da Tabela 2, os consumidores possuem interesse na relação entre natureza, pessoas da comunidade e indústria de vestuário um pouco acima da média $(\mathrm{X} 1, \mathrm{M}=4,2)$, o que pode ser interpretado como alguma indiferença ou ausência de interesse. Esta interpretação parece alinhada com a aparente falta de consciência sobre os impactos que o consumo excessivo tem na natureza $(\mathrm{X} 2, \mathrm{M}=4,1)$, também acima da média.

Comparando os resultados apresentados da preocupação do consumidor com os impactos do consumo na natureza e na comunidade ( $\mathrm{Y} 1, \mathrm{M}=4,7)$, que apresenta uma média superior, é possível perceber uma lacuna entre a percepção de se sentir preocupado e o posicionamento proativo de estar interessado e consciente de tais impactos. Além disso, a comparação dos coeficientes de variação entre essas três variáveis revela que há maior concordância entre os consumidores, em termos de preocupação com o comportamento de consumo na natureza e na comunidade $(\mathrm{Y} 1, \mathrm{CoV}=34 \%)$, mas, menor concordância em termos de interesse e consciência de seu consumo excessivo $(\mathrm{X} 1, \mathrm{CoV}=41 \%$ e X2, CoV $=43 \%)$.

Verificou-se a possibilidade de uma lacuna entre a tendência de se preocupar com a sustentabilidade e a disponibilidade de tempo para focar neste assunto, bem como a atitude de aceitar a responsabilidade pela situação. Essa constatação corrobora com a pesquisa de Pereira Heath e Chatzidakis (2012) que destacaram uma negação de responsabilidade quando consumidores consideravam o sistema de marketing e terceiros - incluindo o sistema educacional ou a sociedade em geral - como responsáveis pela solução dos desafios ambientais. Pode-se identificar, ainda, uma lacuna entre atitudes e comportamentos ambientais, indicando que consumidores que afirmam serem pró meio ambiente podem deixar de sê-lo por razões internas e externas (Zhao, Gao, Wu, Wang \& Zhu, 2014). Esse aspecto torna-se especialmente importante quando os consumidores percebem menos benefícios das alegações de produtos verdes (Pinto, Nique, Añaña, \& Herter 2011; Tseng \& Hung, 2013) ou quando os preços altos e a baixa qualidade se tornam barreiras para aumentar o hábito de compra verdes (Ritter, Borchardt, Vaccaro, Pereira \& Almeida, 2014). 
Entre as variáveis utilizadas para testar os elementos do discurso de marketing, a influência do comprometimento institucional (X12; $\mathrm{M}=5,0)$ sugere que um sinal claro de intenções corporativas (Connelly et al, 2011) pode potencializar um comportamento positivo do consumidor. A importância da sinalização aumenta a influência das avaliações de terceiros na sensibilidade ao preço $(\mathrm{X} 11 ; \mathrm{M}=5,2)$. Ambos os aspectos, compromisso institucional e avaliação de terceiros, lidam com a questão de que governo e organizações são comumente vistos como parte do sistema com uma tendência para o interesse próprio e objetivos de curto prazo, conforme mencionado por Macnaghten et al. (1995) e Ritter et al. (2015).

Finalmente, entre os elementos do discurso de marketing, as abordagens de marketing convencionais, como reportagens de TV (X3, M =4,7), publicidade publicada (X6, M = 4,6), filantropia ou doações $(X 7, M=4,7)$, redes sociais $(X 9, M=4,3)$ e revistas especializadas $(X 10$, $\mathrm{M}=4,8$ ) ainda são importantes como ferramentas de marketing, mas, menos do que as anteriores. A amostra utilizada nesta pesquisa, caracterizada por altos níveis de escolaridade e renda, não é sensível às abordagens convencionais que requerem uma estratégia diferente dos profissionais de marketing, pelo menos, no contexto de produtos verdes na indústria do vestuário.

Para medir a influência da proximidade aos impactos, as altas médias de conexão direta com as pessoas afetadas (X4; $M=5,1)$ e conexão direta com os aspectos afetados da natureza (X5; $\mathrm{M}=5,0)$ sugerem que o marketing ambiental deveria chamar a atenção dos consumidores para aspectos próximos de sua experiência. Conforme mostrado por Broderick et al. (2003), bem como por White et al. (2019), a proximidade com problemas ambientais traz consciência e envolvimento, e o nível emocional de envolvimento individual é um fator determinante na formação do comportamento do consumidor. Portanto, os esforços de marketing de produto sustentável devem se concentrar em questões locais, ao invés de causas gerais e distantes. Assim, o consumidor pode associar o problema às suas próprias experiências, estimulando o comportamento esperado.

Essa mudança é desafiadora quando se trata da cadeia de abastecimento têxtil, já que os impactos ambientais muitas vezes são deixados para trás em áreas agrícolas ou industriais distantes do consumo - como Panamá, China e Sul da Ásia, entre outros países (Programa Internacional de Eliminação da Criança Trabalho [IPEC], 2013). Os consumidores geralmente desconhecem, portanto, que estão em condições de associar essa realidade a um discurso de marketing desenvolvido por uma organização socialmente responsável (Wang, Krishna \& McFerran, 2016) na indústria do vestuário. 
Os resultados do modelo de estimação que evidenciam os fatores estatisticamente significativos que influenciam a decisão de aceitar um diferencial de preço são apresentados na Tabela 4. Com $95 \%$ de confiança apenas as variáveis avaliação de terceiros dos resultados reivindicados pelas organizações $(\mathrm{X} 11$; Beta $=0,386)$ e a capacidade das organizações de incluir os consumidores como parte da solução, despertando de alguma forma um senso de responsabilidade compartilhada $(\mathrm{X} 8 ;$ Beta $=0,222)$, estão estatisticamente relacionados à decisão do consumidor de aceitar um diferencial de preço para produtos de vestuário sustentáveis no mercado brasileiro.

Nesse contexto, verifica-se uma relação direta com o ceticismo do consumidor. Ou seja, os consumidores requerem mecanismos independentes para corroborar as reivindicações organizacionais. O número considerável de produtos sustentáveis no mercado pode explicar, pelo menos em parte, o desenvolvimento desse comportamento. Sob essa perspectiva, essa constatação pode representar uma oportunidade para profissionais de marketing, uma vez que a confiabilidade pode levar à lealdade e, até mesmo, a uma atitude favorável em relação ao pagamento pelo benefício que é esperado pelos consumidores de produtos de vestuário sustentáveis.

A variável utilização da avaliação de terceiros é uma inovação que tem se mostrado relevante para explicar o comportamento do consumidor - no caso de produtos sustentáveis - e reforça a importância da tendência internacional de integração de relatórios financeiros e de sustentabilidade anuais. Essa integração tem sido uma iniciativa de órgãos reguladores e instituições profissionais, como o Sustainability Accounting Standards Board (SASB), o International Integrated Reporting Council (IIRC) e a Global Reporting Initiative (GRI). É o caso de uma empresa brasileira do setor de cosméticos, por exemplo, que está entre as organizações pioneiras a adotar padrões inovadores de demonstrações financeiras anuais com integração de informações sociais, ambientais e financeiras (Eccles \& Serafeim, 2013; Maksudunov \& Avci, 2020).

Quando a negação de responsabilidade é superada pelos esforços de marketing por parte da organização que busca aproximar os consumidores do problema ambiental e compartilhar a responsabilidade pela solução (Han \& Stoel, 2017; White et al, 2019), os consumidores se sentem mais inclinados a comprar seus produtos, apesar dos preços mais altos. Esta pesquisa revela, portanto, um consumidor pouco interessado no assunto e um tanto reativo em assumir sua parcela de responsabilidade. 
Os resultados apresentados são consistentes com as pesquisas de Stall-Meadows e Davey (2013) e de Han e Stoel (2017), que destacaram a importância da credibilidade das afirmações de marketing, as quais precisam ser precisas e verificáveis para ganharem legitimidade. O resultado também está alinhado com os resultados da pesquisa de Peloza et al. (2013), segundo o qual os consumidores podem ser influenciados favoravelmente a aceitarem um preço premium para produtos verdes quando os esforços de marketing conseguem aumentar a consciência do consumidor sobre sua própria responsabilidade, nesse processo. Portanto, os esforços para conscientizar os consumidores sobre seus próprios papéis são fundamentais; uma vez educado, neste sentido, o consumidor pode se comportar positivamente em relação a produtos sustentáveis.

A compreensão mais aprofundada sobre como mudar o comportamento do consumidor para que este seja mais sustentável, ainda permanece uma preocupação geral, conforme destacado por White et al. (2019). Nesse sentido, é importante lembrar que diferentes culturas ao redor do mundo têm impactos diferentes no comportamento do consumidor (Sharaf \& Perumal, 2018). No entanto, hábitos demoram a mudar; embora seja desejável que as opiniões dos respondentes tenham mudado desde o desenvolvimento desta pesquisa, evidências (Gonzalez-Arcos et al, 2021) mostram que, infelizmente, ainda há um longo caminho a percorrer.

\section{Conclusão}

Utilizando o contexto da indústria do vestuário e uma amostra do Brasil, este estudo teve como objetivo identificar as variáveis que podem influenciar os consumidores a pagarem um preço premium pela compra de produtos verdes. A indústria do vestuário foi selecionada devido ao seu potencial impacto, tanto social quanto ambientalmente. O mercado brasileiro pode ser considerado significativo na economia global devido à sua diversificada capacidade industrial e grande população.

Os resultados mostraram que os consumidores estavam apenas moderadamente interessados no tópico da sustentabilidade na indústria do vestuário e estavam apenas moderadamente cientes das consequências do consumo excessivo na qualidade ambiental. No entanto, os consumidores que participaram desta pesquisa mostraram-se preocupados com o impacto de seu comportamento de consumo, tanto na natureza quanto nas comunidades. Parece haver alguma distância entre a tendência de se preocupar com a situação e uma atitude mais positiva. 
Embora não seja significativo para explicar a decisão de pagar um preço premium por produtos sustentáveis, esta pesquisa destaca a importância da proximidade do consumidor com os impactos na natureza e na comunidade. Esse resultado sugere que abordagens que buscam aproximar o consumidor dos problemas causados pelas práticas convencionais de produção podem ser mais eficazes para organizações voltadas à produtos têxteis sustentáveis.

O estudo também mostra que os consumidores são céticos quanto à autenticidade das práticas adotadas pelo governo e organizações. Diante dessa constatação, as organizações devem submeter os resultados de suas iniciativas verdes à terceiros para avaliação, a fim de validarem as práticas adotadas em busca da legitimidade desejada. Nesse sentido, os esforços de marketing por parte de organizações socialmente responsáveis devem envolver os consumidores como parte da solução; isto é, os consumidores devem ser encorajados a aceitar sua responsabilidade de melhorar as condições ambientais. Os resultados desta pesquisa sugerem que esforços devem ser feitos em questões próximas à realidade do consumidor. Além disso, confirmou-se a importância de sinalizar a institucionalização do tema sustentabilidade como parte integrante da estratégia corporativa.

Além de confirmar pesquisas anteriores e fornecer dados estatísticos para aprofundar a discussão sobre o comportamento do consumidor e as atitudes em relação aos produtos sustentáveis, esta pesquisa introduziu uma variável pouco utilizada na literatura: a avaliação de terceiros. A importância da avaliação de terceiros não tem sido comumente adotada para explicar o comportamento do consumidor em relação a produtos sustentáveis. Portanto, este estudo não só inova ao adotar essa variável no modelo, mas, também identifica a importância dessa prática. No que diz respeito à contribuição prática do estudo para os profissionais de marketing, os resultados destacam a importância da legitimidade e do envolvimento dos consumidores na solução dos desafios ambientais.

Uma limitação desta pesquisa está no fato de que a amostra foi não probabilística e transversal, o que não permite generalização dos resultados. No entanto, os achados trazem evidências de comportamentos que podem ser confirmados em estudos futuros por meio de amostragem probabilística e com pesquisas realizadas ao longo do tempo para observar mudanças no comportamento do consumidor. $\mathrm{O}$ fato de esta pesquisa considerar apenas os consumidores brasileiros de um único setor (setor têxtil) também se apresenta como uma limitação. Aspectos culturais e características específicas de cada setor podem afetar os resultados obtidos neste estudo. Recomenda-se que esta pesquisa seja replicada em outros 
países e em outras indústrias, a fim de observar os impactos das diferenças culturais e de diferentes setores da economia. Isso pode contribuir para tornar os resultados mais robustos.

Estudos futuros também podem aprofundar a discussão aqui apresentada, utilizando amostras com pessoas mais jovens. É possível que outra geração pode apresentar postura menos cética, uma vez que a legislação ambiental tem evoluído e o envolvimento dos jovens em causas sociais tem aumentado. Sugere-se, ainda, pesquisar serviços e produtos que tenham uma relação mais próxima com a qualidade ambiental vivenciada pelos consumidores. É o caso dos serviços de transporte e da indústria de óleo e gás, por exemplo, onde a proximidade do consumidor com os impactos decorrentes de tais produtos e serviços poderia apresentar resultados diferentes.

\section{Agradecimentos}

Esta pesquisa foi apoiada pelo Conselho Nacional de Desenvolvimento Científico e Tecnológico (CNPq / Brasil), projeto 304209 / 2018-0 e 425016/2018, pela Fundação de Amparo à Pesquisa do Espírito Santo (FAPES / Brasil), projetos 84513772 (599/2018 ), 555/2018, 85395650 (228/2019), 141/2019 e 30007011003P2 (02/2018), pela Fundação para a Ciência e Tecnologia de Portugal (FCT / Portugal) através do NECE (Núcleo de Estudos em Ciências Empresariais), projeto UID / GES / 04630 / 2020, e pelo IFTS (Instituto Fucape de Tecnologias Sociais), projeto 2018-2021.

\section{Referências}

Akehurst, G., Afonso, C., \& Martins Gonçalves, H. (2012). Re-examining green purchase behaviour and the green consumer profile: New evidences. Management Decision, 50(5), 972-988. https://doi.org/10.1108/00251741211227726

Amoako, G. K., Dzogbenuku, R. K., \& Abubakari, A. (2020). Do green knowledge and attitude influence the youth's green purchasing? Theory of planned behavior. International Journal of Productivity and Performance Management, 69(8), 1609-1626. https://doi.org/10.1108/IJPPM-12-2019-0595

Antonetti, P., \& Maklan, S. (2014). Feelings that make a difference: How guilt and pride convince consumers of the effectiveness of sustainable consumption choices. Journal of Business Ethics, 124(1), 117-134. https://doi.org/10.1007/s10551-013-1841-9

Azasu, S. (2009). Rewards and performance of Swedish real estate firms. Compensation \& Benefits Review, 41(4), 19-28. https://doi.org/10.1177/0886368709337924

Baer, W. (2001). Brazilian economy, the growth and development. Boulder: Lynne Rienner Publishers. 
Barcellos, M. D., Teixeira, C. M., \& Venturini, J. C. (2014). Personal values associated with political consumption: An exploratory study with university students in Brazil.

International Journal of Consumer Studies, 38(2), 207-216.

https://doi.org/10.1111/ijcs.12084

Brandão, M. R., Alexandre, M. L., Anez, M. E., \& Costa, B. K. (2011). Influência dos Stakeholders na adoção de estratégias de marketing verde. Revista Pretexto, 12(4). https://doi.org/10.21714/pretexto.v12i4.822

Brochet, F., Loumioti, M., \& Serafeim, G. (2013). Short-termism, investor clientele, and corporate performance. Harvard Business School Accounting \& Management Unit, 12-72.

Broderick, A., Jogi, A., \& Garry, T. (2003). Tickled pink: The personal meaning of cause related marketing for customers. Journal of Marketing Management, 19(5-6), 583-610. https://doi.org/10.1080/0267257X.2003.9728227

Chan, R. \& Lau, L. B. Y. (2000). Antecedents of Green Purchases: A Survey in China. Journal of Consumer Marketing 17(4):338-357. https://doi.org/10.1108/07363760010335358

Chen, H., \& Burns, L. D. (2006). Environmental analysis of textile products. Clothing and Textiles Research Journal, 24(3), 248-261. https://doi.org/10.1177\%2F0887302X06293065

Chen, Y. S., \& Chang, C. H. (2013). Greenwash and green trust: The mediation effects of green consumer confusion and green perceived risk. Journal of Business Ethics, 114(3), 489-500. https://doi.org/10.1007/s10551-012-1360-0

Choi, S., \& Ng, A. (2011). Environmental and economic dimensions of sustainability and price effects on consumer responses. Journal of Business Ethics, 269-282.

https://doi.org/10.1007/s10551-011-0908-8

Connelly, B. L., Ketchen D. J., Jr., \& Slater, S. F. (2011). Toward a "theoretical toolbox" for sustainability research in marketing. Journal of the Academy of Marketing Science, 39(1), 86-100. https://doi.org/10.1007/s11747-010-0199-0

Diamantopoulos, A., Schlegelmilch, B. B., Sinkovics, R. R., \& Bohlen, G. M. (2003). Can socio-demographics still play a role in profiling green consumers? A review of the evidence and an empirical investigation. Journal of Business Research, 56(6), 465-480. https://doi.org/10.1016/S0148-2963(01)00241-7

Dickson, M. A. (1999). US consumers' knowledge of and concern with apparel sweatshops. Journal of Fashion Marketing and Management: An International Journal, 3(1), 44-55. https://doi.org/10.1108/eb022547

Dickson, M. A., Waters, Y., \& López-Gydosh, D. (2012). Stakeholder Expectations for Environmental Performance within the Apparel Industry. Journal of Corporate Citizenship, 2012(45), 37-51. https://doi.org/10.9774/GLEAF.4700.2012.SP.00005 
Eccles, R. G., Ioannou, I., \& Serafeim, G. (2011). The Impact of Corporate Sustainability on Organizational Processes and Performance. Harvard Business Review Working Paper. Accessed June 20, 2014, at http://ssrn.com/abstract=19640112013 https://doi.org/10.1287/mnsc.2014.1984

Eccles, R. G., \& Serafeim, G. (2013). A Tale of Two Stories: Sustainability and the Quarterly Earnings Call. Journal of Applied Corporate Finance, 25, 8-19. https://doi.org/10.1111/jacf.12023

Edinger-Schons, L., Sipila, J., Sen, S., Mende, G., \& Wieseke, J. (2018). Are Two Reasons Better Than One? The role of appeal type in consumer responses to sustainable products. Journal of Consumer Psychology, 28(4), 644-64. https://doi.org/10.1002/jcpy.1032

Freeman, R. E., Harrison, J. S., \& Wicks, A. C. (2007). Managing For Stakeholders: Survival, Reputation, and Success. New Haven \& London: Yale University Press. https://dx.doi.org/10.2139/ssrn.1186402

Gershoff, A. D., \& Frels, J. K. (2015). What Makes it Green? The role of centrality of green attributes in evaluations of the greenness of products. Journal of Marketing, 79(1), 97-110. https://doi.org/10.1509\%2Fjm.13.0303

Gonzalez-Arcos, C., Joubert, A. M., \& Scaraboto, D. (2021). "How do I carry all this now?" Understanding consumer resistance to sustainability interventions. Journal of Marketing, 85(3), 44-61. https://doi.org/10.1177\%2F0022242921992052

Han, Tae-Im, \& Stoel, L. (2017). Explaining Socially Responsible Consumer Behavior: A meta-analytic review of theory of planned behavior, Journal of International Consumer Marketing, 29(2), 91-103. https://doi.org/10.1080/08961530.2016.1251870

Hong, Z., Wang, H., \& Yu, Y. (2018). Green product pricing with non-green product reference. Transportation Research Part E: Logistics and Transportation Review. 115, 115. https://doi.org/10.1016/j.tre.2018.03.013

International Programme on the Elimination of Child Labour (IPEC). (2013). Marking Progress Against Child Labour - Global estimates and trends (2000-2012). Geneva: International Labour Office (ILO).

Joung, S. H., Park, S. W., \& Ko, Y. J. (2014). Willingness to Pay for Eco-Friendly Products: Case of cosmetics. Asia Marketing Journal, 15(4), 33-49.

Kang, J., Liu, C., \& Kim, S.-H. (2013). Environmentally Sustainable Textile and Apparel Consumption: The role of consumer knowledge, perceived consumer effectiveness and perceived personal relevance. International Journal of Consumer Studies, 37(4), 442-452. https://doi.org/10.1111/ijcs.12013

Koschate-Fischer, N., Stefan, I. V., \& Hoyer, W. D. (2012). Willingness to Pay for CauseRelated Marketing: The impact of donation amount and moderating effects. Journal of Marketing Research, 910-927. https://doi.org/10.1509\%2Fjmr.10.0511 
Lopes, V. N., \& Pacagnan, M. N. (2014). Marketing verde e práticas socioambientais nas indústrias do Paraná. Revista de Administração da Universidade de São Paulo, 49(1). https://doi.org/10.5700/rausp1135

Macnaghten, P., Grove-White, R., Jacobs, M., \& Wynne, B. (1995). Public perceptions and sustainability in Lancashire. Indicators, Institutions, Participation. A report by the Centre for the Study of Environmental Change commissioned by Lancashire County Council. http://dx.doi.org/10.13140/2.1.4038.3360

Mainardes, E. W., Yeh, T., \& Leal, A. (2017). Consumers' Evaluations of the Efficiency of Actions to Improve Environmental Quality: A comparative study between Brazil and China. International Journal of Consumer Studies, 41(6), 659-670. https://doi.org/10.1111/ijcs.12379

Maksudunov, A., \& Avci, M. (2020). The color of the future in marketing is green. In: A. Sekerkaya (Ed.), Contemporary Issues in Strategic Marketing (pp. 225-254). Istanbul: Istanbul University Press. http://dx.doi.org/10.26650/B/SS05.2020.002.07

Marshall, M. N. (1996). Sampling for qualitative research. Family Practice, 13(6), 522-526. https://doi.org/10.1093/fampra/13.6.522

Martinez, M. F. (2010). Variáveis Explicativas da Favorabilidade Ambiental do Consumidor: uma investigação na cidade de São Carlos (Doctoral thesis). Escola de Administração de Empresas de São Paulo, São Paulo. http://hdl.handle.net/10438/8166

McDonald, S. \& Oates, C. J. (2006). Sustainability: Consumer Perceptions and Marketing Strategies. Business Strategy and the environment, 15(3), 157-170. https://doi.org/10.1002/bse.524

Menon, A., \& Menon, A. (1997). Enviropreneurial Marketing Strategy: The emergence of corporate environmentalism as market strategy. The Journal of Marketing, 51-67. https://doi.org/10.1177\%2F002224299706100105

Moulds, J. (2015). Child Labour in the Fashion Supply Chain: Where, why and what can be done. The Guardian. https://www.theguardian.com/sustainable-business/nginteractive/2015/jan/19/child-labour-in-the-fashion-supply-chain

Paine, L. S. (2004). Value Shift: Why companies must merge social and financial imperatives to achieve superior performance. New York: McGraw Hill Professional. doi:0071427333, 9780071427333 https://doi.org/10.5465/ame.2003.10025213

Peattie, K. (1999). Trappings versus substance in the greening of marketing planning. Journal of Strategic Marketing, 7(2), 131-148. https://doi.org/10.1080/096525499346486

Peattie, K. (2001). Towards Sustainability: The third age of green marketing. The Marketing Review, 2(2), 129-146. https://doi.org/10.1362/1469347012569869

Peattie, K. (2010). Green Consumption: Behavior and Norms. Annual Review of Environment and Resources, 35(1), 195-228. https://doi.org/10.1146/annurev-environ-032609-094328 
Peloza, J., White, K., \& Shang, J. (2013). Good and Guilt-Free: The role of selfaccountability influencing preferences for products with ethical attribute. Journal of Marketing, 77(1), 104-119. https://doi.org/10.1509\%2Fjm.11.0454

Pereira Heath, M. T., \& Chatzidakis, A. (2012). Blame it on Marketing: Consumers' views on unsustainable consumption. International Journal of Consumer Studies, 36(6), 656-667. https://doi.org/10.1111/j.1470-6431.2011.01043.x

Pinto, D. C., Nique, W. M., Añaña, E. D., \& Herter, M. M. (2011). Green Consumer Values: How do personal values influence environmentally responsible water consumption? International Journal of Consumer Studies, 35(2), 122-131. https://doi.org/10.1111/j.14706431.2010.00962.x

Pristl A-C., Kilian S., \& Mann A. (2021). When Does a Social Norm Catch the Worm? Disentangling social normative influences on sustainable consumption behavior. Journal of Consumer Behavior. Special Issue Article, 1-20. https://doi.org/10.1002/ cb.1890

Ranjan, R. K. (2019). Green Marketing: An exploration through qualitative research. Global Journal of Management and Business Research, [S.1.], Jan., 2249-4588. https://journalofbusiness.org/index.php/GJMBR/article/view/2989

Ribeiro, J. de A., \& Veiga, R. T. (2011). Proposição de uma escala de consumo sustentável. Revista de Administração da Universidade de São Paulo, 46(1). https://doi.org/10.5700/rausp0997

Ritter, A. M., Borchardt, M., Vaccaro, G. L. R., Pereira, G. M., \& Almeida, F. (2015). Motivations for Promoting the Consumption of Green Products in an Emerging Country: Exploring attitudes of Brazilian consumers. Journal of Cleaner Production, 106, 507-520. https://doi.org/10.1016/j.jclepro.2014.11.066

Roberts, J. A. (1996). Green Consumers in the 1990s: Profile and implications for advertising. Journal of Business Research, 36(3), 217-231. https://doi.org/10.1016/01482963(95)001506

Rolli, C. (2014, Set 29). Marca de luxo é ligada a trabalho degradante. Retrieved from Folha de São Paulo: http://www1.folha.uol.com.br/mercado/2013/07/1317521-marca-de-luxo-eligada-a-trabalho-degradante.shtml

Sharaf, M. A., \& Perumal, S. (2018). How does green products' price and availability impact Malasyans' green purchasing behavior? The Journal of Social Sciences Research, 4(3), 2834. https://ideas.repec.org/a/arp/tjssrr/2018p28-34.html

Singh, R., \& Vij, S. (2011). Dimensions of Consumers' Advertising Beliefs in India. Indian Journal of Marketing, 41(3), 21-32.

Solihin, F., Yulisetiarini, D., Wihelmina, I. D., \& Wardana, F. R. (2019). The Effect of Green Marketing Strategy on Purchasing Decisions: A review of previous research. International Journal of Scientific \& Technology Research, 8(12), 3662-3665. http://www.ijstr.org/finalprint/dec2019/The-Effect-Of-Green-Marketing-Strategy-On-Purchasing-Decisions-AReview-Of-Previous-Research.pdf 
Spence, A., Poortinga, W., \& Pidgeon, N. (2012). The psychological distance of climate change. Risk Analysis, 32(6), 957-972. https://doi.org/10.1111/j.1539-6924.2011.01695.x

Stall-Meadows, C., \& Davey, A. (2013). Green Marketing of Apparel: Consumers' price sensitivity to environmental marketing claims. Journal of Global Fashion Marketing, 3343. https://doi.org/10.1080/20932685.2012.753293

Straughan, R. D., \& Roberts, J. A. (1999). Environmental Segmentation Alternatives: A look at green consumer behavior in the new millennium. Journal of Consumer Marketing, 16(6), 558-575. https://doi.org/10.1108/07363769910297506

Taufique, K. M. R., Vocino, A., \& Polonsky, M. J. (2017). The influence of eco-label knowledge and trust on pro-environmental consumer behaviour in an emerging market. Journal of Strategic Marketing, 25(7), 511-29. https://doi.org/10.1080/0965254X.2016.1240219

Tseng, S. C., \& Hung, S. W. (2013). A framework identifying the gaps between customers' expectations and their perceptions in green products. Journal of cleaner production, 59, 174-184. https://doi.org/10.1016/j.jclepro.2013.06.050

Varadarajan, P. R. (1992). Marketing's Contribution to Strategy: The view from a different looking glass. Journal of the Academy of Marketing Science, 20(4), 335-343. https://doi.org/10.1177\%2F0092070392204008

Varadarajan, P. R., \& Menon, A. (1988). Cause-Related Marketing: A coalignment of marketing strategy and corporate philanthropy. The Journal of Marketing, 58-74. https://doi.org/10.1177\%2F002224298805200306

Wang, W., Krishna, A., \& McFerran, B. (2016). Turning Off the Lights: Consumers' environmental efforts depend on visible efforts of firms. Journal of Marketing Research, 54(3), 478-494. https://doi.org/10.1509\%2Fjmr.14.0441

White, K., Habid, R., \& Hardisty, D. J. (2019). How to SHIFT Consumer Behaviors to be More Sustainable: A literature review and guiding framework. Journal of Marketing, 83(3) 22-49. https://doi.org/10.1177\%2F0022242919825649

Zadeh, A. H., Zolfagharian, M., \& Hofacker, C. (2019). Customer-Customer Value CoCreation in Social Media: Conceptualization and antecedents, Journal of Strategic Marketing, 27(4), 283-302. https://doi.org/10.1080/0965254X.2017.1344289

Zhao, H. H., Gao, Q., Wu, Y. P., Wang, Y., \& Zhu, X. D. (2014). What Affects Green Consumer Behavior in China? A case study from Qingdao. Journal of Cleaner Production, 63, 143-151. https://doi.org/10.1016/j.jclepro.2013.05.021

Apêndice 1 - Variáveis 


\begin{tabular}{|c|c|c|c|c|}
\hline Código & Variável & Referência & $\begin{array}{l}\text { Método de } \\
\text { mensuração }\end{array}$ & Tipo \\
\hline $\mathrm{X} 1$ & $\begin{array}{l}\text { Interesse na relação entre a natureza, } \\
\text { pessoas da comunidade e indústria de } \\
\text { vestuário }\end{array}$ & $\begin{array}{l}\text { (Macnaghten et al., } \\
\text { 1995; Straughan \& } \\
\text { Roberts, 1999) }\end{array}$ & $\begin{array}{l}\text { Escala de Likert de sete } \\
\text { posições } \\
\text { totalmente e } \\
\text { totalmente) }\end{array}$ & Independente \\
\hline $\mathrm{X} 2$ & $\begin{array}{l}\text { Conscientização dos impactos do } \\
\text { consumo excessivo na natureza }\end{array}$ & $\begin{array}{l}\text { Pereira Heath \& } \\
\text { Chatzidakis, 2012; } \\
\text { Straughan \& } \\
\text { Roberts,1999) }\end{array}$ & $\begin{array}{lr}\begin{array}{l}\text { Escala de Likert de sete } \\
\text { posições }\end{array} \\
\text { totalmente e } \\
\text { totalmente) }\end{array}$ & Independente \\
\hline $\mathrm{X} 3$ & $\begin{array}{l}\text { Influência na sensibilidade ao preço de } \\
\text { reportagens de televisão mostrando } \\
\text { resultados reais }\end{array}$ & $\begin{array}{l}\text { (Connelly et al., } \\
\text { 2011) }\end{array}$ & $\begin{array}{l}\text { Escala de Likert de sete } \\
\text { posições (discordo } \\
\text { totalmente e concordo } \\
\text { totalmente) }\end{array}$ & Independente \\
\hline $\mathrm{X} 4$ & $\begin{array}{l}\text { Influência na sensibilidade ao preço da } \\
\text { conexão direta com as pessoas } \\
\text { afetadas }\end{array}$ & $\begin{array}{l}\text { (Broderick et al., } \\
\text { 2003) }\end{array}$ & $\begin{array}{lr}\text { Escala de Likert de sete } \\
\text { posições } & \text { (discordo } \\
\text { totalmente e } & \text { concordo } \\
\text { totalmente) } & \\
\end{array}$ & Independente \\
\hline $\mathrm{X} 5$ & $\begin{array}{l}\text { Influência na sensibilidade ao preço de } \\
\text { uma conexão direta com aspectos da } \\
\text { natureza afetados }\end{array}$ & $\begin{array}{l}\text { (Broderick et al., } \\
\text { 2003) }\end{array}$ & $\begin{array}{lr}\text { Escala de Likert de sete } \\
\text { posições } & \text { (discordo } \\
\text { totalmente e } & \text { concordo } \\
\text { totalmente) } & \\
\end{array}$ & Independente \\
\hline X6 & $\begin{array}{l}\text { Influência na sensibilidade ao preço da } \\
\text { publicidade direta na mídia }\end{array}$ & $\begin{array}{l}\text { (Connelly, et al., } \\
\text { 2011) }\end{array}$ & $\begin{array}{lr}\text { Escala de Likert de sete } \\
\text { posições } & \text { (discordo } \\
\text { totalmente e } & \text { concordo } \\
\text { totalmente) } & \\
\end{array}$ & Independente \\
\hline $\mathrm{X} 7$ & $\begin{array}{l}\text { Influência na sensibilidade ao preço da } \\
\text { filantropia ou doações }\end{array}$ & $\begin{array}{l}\text { (Varadarajan } \quad \& \\
\text { Menon, 1988) }\end{array}$ & $\begin{array}{lr}\text { Escala de Likert de sete } \\
\text { posições } & \text { (discordo } \\
\text { totalmente e } & \text { concordo } \\
\text { totalmente) } & \\
\end{array}$ & Independente \\
\hline $\mathrm{X} 8$ & $\begin{array}{l}\text { Influência na sensibilidade ao preço de } \\
\text { compartilhar a responsabilidade com o } \\
\text { consumidor }\end{array}$ & (Peloza et al., 2013) & $\begin{array}{l}\text { Escala de Likert de sete } \\
\text { posições } \\
\text { totalmente e } \\
\text { totalmente) }\end{array}$ & Independente \\
\hline X9 & $\begin{array}{l}\text { Influência na sensibilidade ao preço de } \\
\text { recursos por meio de redes sociais }\end{array}$ & (Kang et al., 2013) & $\begin{array}{lr}\text { Escala de Likert de sete } \\
\text { posições } & \text { (discordo } \\
\text { totalmente e } & \text { concordo } \\
\text { totalmente) } & \\
\end{array}$ & Independente \\
\hline $\mathrm{X} 10$ & $\begin{array}{l}\text { Influência na sensibilidade ao preço de } \\
\text { recursos por meio de artigos em } \\
\text { revistas especializadas }\end{array}$ & $\begin{array}{l}\text { (Macnaghten et al., } \\
\text { 1995; Connelly et } \\
\text { al., 2011) }\end{array}$ & $\begin{array}{l}\text { Escala de Likert de sete } \\
\text { posiçõos } \\
\text { totalmente e } \\
\text { totalmente) }\end{array}$ & Independente \\
\hline $\mathrm{X} 11$ & $\begin{array}{l}\text { Influência na sensibilidade ao preço de } \\
\text { avaliações de terceiros }\end{array}$ & $\begin{array}{l}\text { (Macnaghten et al., } \\
\text { 1995; Connelly et } \\
\text { al., 2011) }\end{array}$ & $\begin{array}{lr}\text { Escala de Likert de sete } \\
\text { posições } & \text { (discordo } \\
\text { totalmente e } & \text { concordo } \\
\text { totalmente) } & \end{array}$ & Independente \\
\hline $\mathrm{X} 12$ & $\begin{array}{l}\text { Influência na sensibilidade ao preço do } \\
\text { compromisso institucional }\end{array}$ & $\begin{array}{l}\text { (Connelly et al., } \\
\text { 2011; Menon \& } \\
\text { Menon, 1997) }\end{array}$ & $\begin{array}{l}\text { Escala de Likert de sete } \\
\text { posições } \\
\text { totalmente e } \\
\text { totalmente) }\end{array}$ & Independente \\
\hline Y1 & $\begin{array}{l}\text { Preocupação com os impactos do } \\
\text { comportamento de consumo na } \\
\text { natureza e nas comunidades }\end{array}$ & $\begin{array}{l}\text { (Pereira Heath \& } \\
\text { Chatzidakis, 2012; } \\
\text { Straughan \& } \\
\text { Roberts,1999) }\end{array}$ & $\begin{array}{l}\text { Escala de Likert de sete } \\
\text { posiçõos } \\
\text { totalmente e } \\
\text { totalmente) }\end{array}$ & Dependente \\
\hline Idade & A sua idade é: & --- & Múltipla escolha & Controle \\
\hline Gênero & Seu gênero: & --- & Múltipla escolha & Controle \\
\hline Educação & Sua educação formal: & --- & Múltipla escolha & Controle \\
\hline Renda & Seu nível de renda mensal bruta é: & --- & Múltipla escolha & Controle \\
\hline
\end{tabular}

Fonte: Elaborado pelos autores. 
Apêndice 2 - Análises Complementares de Correlação

\begin{tabular}{|c|c|c|c|c|c|c|c|c|c|c|c|c|c|c|}
\hline & & Y1 & $\mathrm{X} 1$ & $\mathrm{X} 2$ & X3 & $\mathrm{X} 4$ & $\mathrm{X} 5$ & X6 & $\mathrm{X} 7$ & $\mathrm{X} 8$ & $\mathrm{X} 9$ & $\mathrm{X} 10$ & $\mathrm{X} 11$ & $\mathrm{X} 12$ \\
\hline Correlação & Y1 & 1,000 & ,452 & ,498 & ,364 & ,388 & ,444 &, 372 & ,379 & ,445 & ,359 & ,446 & .516 & ,499 \\
\hline \multirow[t]{12}{*}{ de Pearson } & $\mathrm{X} 1$ & ,452 & 1,000 &, 744 &, 378 & ,209 &, 324 &, 336 &, 307 & ,341 & ,341 &, 353 & .319 &, 350 \\
\hline & $\mathrm{X} 2$ & ,498 &, 744 & 1,000 & .324 & .218 & .338 & 330 & 316 & 267 & .332 &, 323 & .306 & 317 \\
\hline & X3 & ,364 & ,378 & ,324 & 1,000 & 614 & 608 & ,709 & ,554 & ,565 &, 523 & ,632 & .590 & 643 \\
\hline & $\mathrm{X} 4$ & ,388 & 209 & ,218 & 614 & 1,000 & ,788 & ,621 & ,544 &, 522 &, 506 & ,669 & .763 & ,708 \\
\hline & $\mathrm{X} 5$ & ,444 &, 324 & ,338 & 608 & ,788 & 1,000 & ,679 & ,581 &, 547 &, 547 & ,746 & .814 & ,768 \\
\hline & $\mathrm{X} 6$ & ,372 & ,336 & ,330 & ,709 & 621 & ,679 & 1,000 & ,723 & 661 &, 540 & 689 & .683 & ,724 \\
\hline & $\mathrm{X} 7$ &, 379 & ,307 &, 316 &, 554 &, 544 &, 581 &, 723 & 1,000 & ,656 & 605 & ,638 & .645 & 653 \\
\hline & $\mathrm{X} 8$ & ,445 & ,341 & 267 &, 565 &, 522 & ,547 & ,661 & ,656 & 1,000 & 604 & ,631 & .604 & ,631 \\
\hline & $\mathrm{X} 9$ & ,359 & 341 & ,332 &, 523 &, 506 & ,547 &, 540 & ,605 & ,604 & 1,000 & 662 & .590 &, 539 \\
\hline & $\mathrm{X} 10$ & ,446 & ,353 & ,323 & ,632 & 669 & ,746 & ,689 & 638 & 631 & ,662 & 1,000 & .798 &, 778 \\
\hline & $\mathrm{X} 11$ &, 516 & ,319 & ,306 &, 590 & ,763 & ,814 & 683 & 645 & ,604 &, 590 & ,798 & 1.000 &, 834 \\
\hline & $\mathrm{X} 12$ & ,499 & 350 & 317 & 643 &, 708 &, 768 &, 724 & 653 & 631 & .539 &, 778 & .834 & 1,000 \\
\hline
\end{tabular}

Fonte: Dados da pesquisa.

\section{Anova $^{a}$}

\begin{tabular}{|c|c|c|c|c|c|c|}
\hline & Modelo & Soma de quadrados & df & Quadrado médio & $\bar{Z}$ & Sig. \\
\hline \multirow{3}{*}{3} & Regressão & 207,848 & 3 & 69,283 & \multirow[t]{3}{*}{39,765} & \multirow[t]{3}{*}{, $000^{\mathrm{d}}$} \\
\hline & Resíduo & 461,706 & 265 & 1,742 & & \\
\hline & Total & 669,554 & 268 & & & \\
\hline
\end{tabular}

Fonte: Dados da pesquisa. a. Variável dependente: Y1. d. Preditores: (Constante), X11, X8, ID. 